\title{
Proteome reveals antiviral host response and NETosis during acute COVID-19 in high-risk patients
}

\author{
Alina Bauer ${ }^{1^{*}}$, Elisabeth Pachl ${ }^{1,2^{*}}$, Johannes C. Hellmuth ${ }^{3,4,5 *}$, Nikolaus Kneidinger ${ }^{6,7}$, Marion \\ Frankenberger ${ }^{6}$, Hans C. Stubbe ${ }^{5,8}$, Bernhard Ryffel ${ }^{9}$, Agnese Petrera ${ }^{10}$, Stefanie M. Hauck ${ }^{10}$, \\ Jürgen Behr ${ }^{6,7}$, Rainer Kaiser ${ }^{5,11}$, Clemens Scherer ${ }^{5,11}$, Li Deng ${ }^{1,12}$, Daniel Teupser ${ }^{13}$, Narges \\ Ahmidi $^{2}$, Maximilian Muenchhoff ${ }^{5,14,15 *}$, Benjamin Schubert ${ }^{1,16 *}$, Anne Hilgendorff ${ }^{6,17+*}$ \\ * These authors contributed equally to this work. \\ + Corresponding Author: anne.hilgendorff@med.uni-muenchen.de
}

${ }^{1}$ Helmholtz Zentrum München, Computational Health Department, Member of the German Center for Lung Research (DZL), 85764 Munich, Germany

${ }^{2}$ Fraunhofer IKS, Fraunhofer Institute for Cognitive Systems IKS, 80686 Munich, Germany

${ }^{3}$ Department of Medicine III, University Hospital, LMU Munich, Munich, Germany

${ }^{4}$ German Cancer Consortium (DKTK), Munich, Germany

${ }^{5}$ COVID-19 Registry of the LMU Munich (CORKUM), University Hospital, LMU Munich, Munich, Germany

${ }^{6}$ Institute of Lung Biology and Disease and Comprehensive Pneumology Center with the CPC-M bioArchive, Helmholtz Zentrum Muenchen, Member of the German Center for Lung Research (DZL), Munich, Germany

${ }^{7}$ Department of Medicine V, University Hospital, LMU Munich, Member of the German Center for Lung Research (DZL), Munich, Germany

${ }^{8}$ Department of Medicine II, University Hospital, LMU Munich, Munich, Germany

${ }^{9}$ Laboratory of Experimental and Molecular Immunology and Neurogenetics (INEM), UMR 7355 CNRS-University of Orleans and Artimmune, Orléans, France

${ }^{10}$ Metabolomics and Proteomics Core, Helmholtz Zentrum München, Munich, Germany

${ }^{11}$ Medizinische Klinik und Poliklinik I, University Hospital, LMU Munich, Munich, Germany, DZHK (German Center for Cardiovascular Research), Partner Site Munich Heart Alliance, Munich, Germany

${ }^{12}$ Institute of Virology, Technical University of Munich, 81675 Munich, Germany

${ }^{13}$ Institute of Laboratory Medicine, University Hospital, LMU Munich, Munich, Germany

${ }^{14}$ Max von Pettenkofer Institute and Gene Center, Virology, National Reference Center for Retroviruses, LMU München, Munich, Germany

${ }^{15}$ German Center for Infection Research (DZIF), partner site Munich, Munich, Germany

${ }^{16}$ Department of Mathematics, Technical University of Munich, 85748 Garching bei München, Germany

${ }^{17}$ Center for Comprehensive Developmental Care $\left(\mathrm{CDeC}^{\mathrm{LMU}}\right)$ at the interdisciplinary Social Pediatric Center (iSPZ), LMU Hospital, Munich, Germany

Running title: High-risk COVID-19 antiviral/NETosis profile

Key words: biomarker, COVID-19, immune response, NETosis, proteomics, high-risk patients 
medRxiv preprint doi: https://doi.org/10.1101/2022.03.02.22271106; this version posted March 6, 2022. The copyright holder for this preprint (which was not certified by peer review) is the author/funder, who has granted medRxiv a license to display the preprint in perpetuity.

\section{Abstract (175 words)}

SARS-CoV-2 remains an acute threat to human health, endangering hospital capacities worldwide. Many studies have aimed at informing pathophysiologic understanding and identification of disease indicators for risk assessment, monitoring, and therapeutic guidance. While findings start to emerge in the general population, observations in high-risk patients with complex pre-existing conditions are limited.

To this end, we biomedically characterized quantitative proteomics in a hospitalized cohort of COVID-19 patients with mild to severe symptoms suffering from different (co)-morbidities in comparison to both healthy individuals and patients with non-COVID related inflammation. Deep clinical phenotyping enabled the identification of individual disease trajectories in COVID-19 patients. By the use of this specific disease phase assignment, proteome analysis revealed a severity dependent general type-2 centered host response side-by-side with a disease specific antiviral immune reaction in early disease. The identification of phenomena such as neutrophil extracellular trap (NET) formation and a pro-coagulatory response together with the regulation of proteins related to SARS-CoV-2-specific symptoms by unbiased proteome screening both confirms results from targeted approaches and provides novel information for biomarker and therapy development. 
medRxiv preprint doi: https://doi.org/10.1101/2022.03.02.22271106; this version posted March 6, 2022. The copyright holder for this preprint (which was not certified by peer review) is the author/funder, who has granted medRxiv a license to display the preprint in perpetuity.

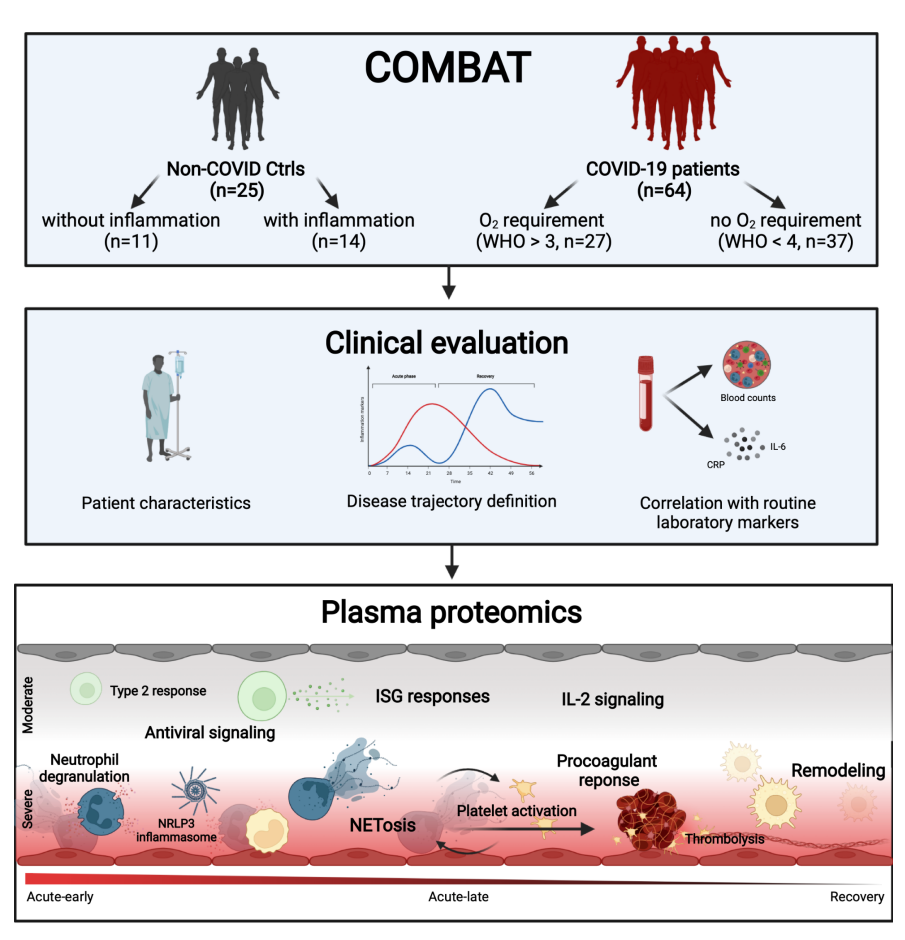

Graphical Abstract. Sars-CoV-2 remains a challenging threat to our health care system with many pathophysiological mechanisms not fully understood, especially in high-risk patients. Therefore, we characterized a cohort of hospitalized COVID-19 patients with multiple comorbidities by quantitative plasma proteomics and deep clinical phenotyping. The individual patient's disease progression was determined and the subsequently assigned proteome profiles compared with a healthy and a chronically inflamed control cohort. The identified disease phase and severity specific protein profiles revealed an antiviral immune response together with coagulation activation indicating the formation of NETosis side-by-side with tissue remodeling related to the inflammatory signature . 
medRxiv preprint doi: https://doi.org/10.1101/2022.03.02.22271106; this version posted March 6, 2022. The copyright holder for this preprint (which was not certified by peer review) is the author/funder, who has granted medRxiv a license to display the preprint in perpetuity. It is made available under a CC-BY-NC-ND 4.0 International license .

\section{Introduction}

The SARS-CoV-2 pandemic continues to pose an immediate threat to global health. As of January 2022, worldwide COVID-19 cases exceed 250 million and deaths have surpassed 5,4 million (WHO Coronavirus (COVID-19) Dashboard). Clinical manifestations vary from asymptomatic carrier to severe illness, organ dysfunction, chronic health impairment including long-COVID, and death (Williamson et al, 2020). To gain deeper insight and inform patient care, epidemiological approaches addressed clinical characteristics of different SARS-CoV-2 infection phases in the overall population and identified risk factors for adverse outcomes such as diabetes or hyperlipidemia (Chen et al, 2020b; Huang et al, 2020; Guan et al, 2020). Studies focused on the identification of clinical signs and early markers that reliably enable monitoring and treatment strategies (Liu et al, 2020b; Zhou et al, 2020) including nationwide approaches stemming from the United Kingdom, Germany, France, Israel, and the USA (Williamson et al, 2020; Nachtigall et al, 2020; Piroth et al, 2021). While these attempts are already challenging in the general population (Booth et al, 2021; Hodges et al, 2020; Williamson et al, 2020), the aim has yet to be reached in cohorts of high-risk patients characterized by a complex picture of preexisting comorbidities. Care for these patients results in resource-intensive monitoring and treatment and thus remains a critical hurdle even for maximum care hospitals. Poor vaccination response rates in a large number of such complex cases and vaccine breakthroughs further complicate the picture (Boyarsky et al, 2021; Malinis et al, 2021; Juthani et al, 2021).

Characterization of immune phenomena such as the 'cytokine storm' (Yang et al, 2021; Buszko et al, 2021) helped to guide treatment initiation and aided first therapeutic approaches (Chen et al, 2020b; Huang et al, 2020; Zhang et al, 2020a). Changes in human plasma protein levels have been suggested as disease indicators (Shu et al, 2020; Messner et al, 2020; Park et al, 2020), in line with the implementation of protein markers for other viral diseases (Oxford et al, 2016). The analyses were furthermore used to gain pathophysiological insight in order to develop new therapeutic strategies (Demichev et al, 2021; Haljasmägi et al, 2020; Filbin et al, 2021).

To increase pathophysiologic insight and enable the identification of disease indicators in high-risk COVID-19 patients with significant preexisting conditions to 
medRxiv preprint doi: https://doi.org/10.1101/2022.03.02.22271106; this version posted March 6, 2022. The copyright holder for this preprint

(which was not certified by peer review) is the author/funder, who has granted medRxiv a license to display the preprint in perpetuity. It is made available under a CC-BY-NC-ND 4.0 International license .

inform monitoring and treatment decisions in the most important disease phases, we profiled host responses to SARS-CoV-2 infection by the use of quantitative plasma proteomics. Tracing disease trajectories by individual expression of inflammation markers enabled us to improve general time-of-infection-based approaches (Schulte-Schrepping et al, 2020).

We thereby successfully identified disease grade and disease phase-specific proteome profiles side-by-side with the regulation of characteristic routine laboratory variables in a high-risk, multimorbid patient cohort. Our study included survivors and non-survivors from COVID-19 and a range from mild to severe disease symptoms compared to patients with acute non-COVID-19 related inflammation, as well as non-inflammatory control cases. We thereby delineated both COVID-19-specific and general immune responses together with the phase-specific involvement of coagulation and remodeling processes as well as the differential regulation of proteins related to SARS-CoV-2-specific symptoms with the potential to significantly inform monitoring and treatment approaches. 
medRxiv preprint doi: https://doi.org/10.1101/2022.03.02.22271106; this version posted March 6, 2022. The copyright holder for this preprint (which was not certified by peer review) is the author/funder, who has granted medRxiv a license to display the preprint in perpetuity.

\section{Results}

\section{Assignment to disease severity revealed differences in patient characteristics at admission}
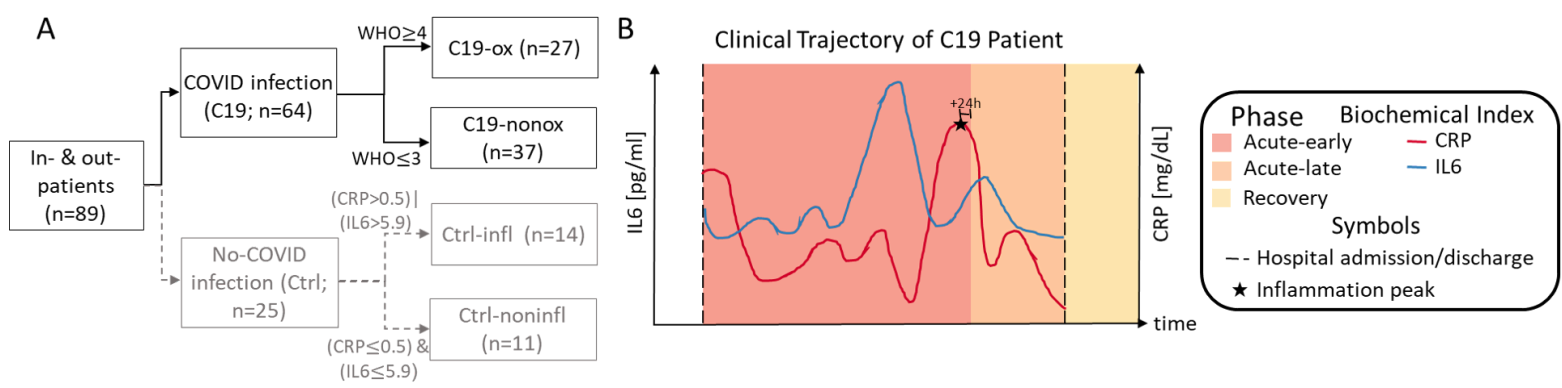

Figure 1. A: Patient number per study group considering C19 (black, solid) and non-C19 patients (gray, dashed); B: Exemplary COVID-19 disease trajectory based on routine biochemical indices IL-6 (blue) and CRP (red) during the hospital stay (dashed black lines) considering the respective disease phases (acute-early, acute-late, and recovery phase).

The study prospectively enrolled 64 patients with PCR confirmed SARS-CoV-2 infection during the first phase of the COVID-19 pandemic in Germany (03/2020 to 08/2020), before steroid treatment for SARS-CoV-2 was routinely prescribed. Patients were enrolled shortly before or at the onset of the acute infection phase when laboratory signs of infection and disease-specific symptoms develop. Twenty-five patients with acute (inflammatory control group; Ctrl-infl) or no/low non-COVID-19 related inflammation (healthy control group; Ctrl-noninfl) were additionally included in the study as control groups (see Materials and Methods Clinical Data Collection, patient grouping, and disease phase assignment, and Table 1).

A maximum WHO score $\geq 4$ (Blueprint, 2020) during the hospital stay was observed in 27 patients (C19-ox group) and $\leq 3$ in 37 patients (C19-nonox group) (Figure 1A). The disease severity groups showed differences in age and gender (age: C19-ox: 70 (IQR 59-79); C19-nonox: 57 (IQR 48-70); females: C19-ox: 37.0\%; C19-nonox group: $32.4 \%$ ), whereas no difference was observed for the time between symptom onset and hospitalization (C19-ox: 5 (IQR 1-8); C19-nonox: 5 (IQR 2-9) (days)) in contrast to a greater length of hospital stay in C19-ox patients (C19-ox: 12 (IQR 12-56); C19-nonox: 10 (IQR 7-17)). Most prevalent symptoms for C19-ox and C19-nonox patients were dyspnea (59.3\%; 37.8\%), fever (51.9\%; $54.1 \%)$, fatigue 
medRxiv preprint doi: https://doi.org/10.1101/2022.03.02.22271106; this version posted March 6, 2022. The copyright holder for this preprint (which was not certified by peer review) is the author/funder, who has granted medRxiv a license to display the preprint in perpetuity.

(51.9\%; $29.7 \%)$, and dry cough (48.2\%; 48.7\%). Both C19-ox and -nonox patients presented with different comorbidities including cardiovascular disease $(66.7 \%$; $64.9 \%)$, pre-existing lung disease $(33.3 \% ; 13.5 \%)$, immune compromise $(37.0 \%$; $24.3 \%)$, diabetes $(33.3 \% ; 18.9 \%)$, and hyperlipidemia $(22.2 \% ; 18.9 \%)$. In the course of the disease, some patients suffered from acute kidney failure (C19-ox: 11.1\%; C19-nonox: $2.7 \%$ ), whereas secondary bacterial, fungal, and/or viral infections ('superinfection') occurred more frequently in C19-ox patients (C19-ox: 44.4\%; C19-nonox: $27.0 \%$ ). $22.2 \%$ and $44.4 \%$ of patients in the C19-ox group underwent non-invasive or invasive ventilation. Therapeutic interventions including antibiotic (C19-ox: 81.5\%; C19-nonox: 64.9\%) and antithrombotic therapy (C19-ox: 59.3\%; C19-nonox: 62.2\%), parenteral nutrition (C19-ox: 37.0\%; C19-nonox: 50.0\%), non-opioid analgesics (C19-ox: 33.3\%; C19-nonox: 40.5\%) were administered in the majority of $\mathrm{C} 19$ patients irrespective of disease severity. Asthma therapy (C19-ox: 55.6\%; C19-nonox: 8.1\%) and antiviral treatment (C19-ox: 44.4\%; C19-nonox: $16.2 \%)$ were used more frequently in higher disease grades.

Non-C19 patients were assigned to the two control groups based on levels of the inflammatory markers IL-6 and CRP, Ctrl-infl $(n=14)$ and Ctrl-noninfl $(n=11)$ (Table 1). Median age in years did not differ between both control groups (Ctrl-infl: 74 (IQR 61-67); Ctrl-noninfl: 69 (IQR 51-75)), whereas female patients were more frequent in the Ctrl-noninfl group (Ctrl-infl: 14.3\%; Ctrl-noninfl: 36.7\%). The median length of hospital stay (in days) was 9 (IQR 7-12) in Ctrl-infl and 1 (IQR 0-2) in Ctrl-noninfl. Ctrl-infl and Ctrl-noninfl patients were characterized by a high prevalence of comorbidities including cardiovascular disease $(85.7 \%$; $63.6 \%)$, pre-existing lung disease (14.3\%; 36.4\%), immune deficiency $(50.5 \%$; $9.1 \%)$, hyperlipidemia $(28.6 \%$; $18.2 \%)$, and diabetes $(21.4 \% ; 18.2 \%)$. Patient characteristics at hospital admission for all study groups are presented in Table S1 \& S2, details about the results of performed statistical tests are shown in Table S3.

\section{Identification of distinct clinical trajectories for disease-severity and -phase assignment}

Next to disease-severity assignment according to the WHO criteria (Blueprint, 2020), we grouped samples of the $64 \mathrm{C} 19$ patients in three distinct disease phases - 
medRxiv preprint doi: https://doi.org/10.1101/2022.03.02.22271106; this version posted March 6, 2022. The copyright holder for this preprint (which was not certified by peer review) is the author/funder, who has granted medRxiv a license to display the preprint in perpetuity. It is made available under a CC-BY-NC-ND 4.0 International license .

acute-early, acute-late, and recovery - based on the individual trajectory of the inflammation markers IL-6 [pg/ml] and CRP [mg/dl] (Figure 1B, Figure S1, see Materials and Methods - Clinical Data Collection, patient grouping, and disease phase assignment). Forty-four samples of 35 patients were assigned to the C19 acute-early phase (interval from disease onset/or first positive PCR test until inflammation peak). Forty-four samples of 40 patients were assigned to the acute-late phase (interval from inflammation peak to discharge), whereas 15 samples of 13 patients were assigned to the recovery phase (after discharge). For significance tests, one sample per individual was used to avoid autocorrelation (see Material and Methods - Data analysis).

This disease phase assignment was found to increase the fit of clinical symptoms and critical events, e.g., ICU admission or the initiation of oxygen treatment to the early disease phase (Figure 2A (left)) in comparison to general time-of-infection based approaches that define disease phases by days from symptom onset $(0-10$ days, early phase; 10 days-discharge, late phase) (Schulte-Schrepping et al, 2020) (Figure 2A (right)). In addition, we showed CRP and IL-6 values to be statistically different when comparing the acute-early and acute-late disease phase (CRP: P-value<0.01; IL-6: P-value<0.01), as expected per design of phase assignment, whereas the disease phases based on the general time-of-infection approaches did not show significant differences for these routine markers (CRP: P-value=0.57; IL-6: P-value $=0.40$ ), indicating poor separation of subgroups (Figure 2B).

Quantitatively comparing the discriminatory power of the two approaches, we analyzed the overall earth mover's distance (EMD) (Rubner et al, 2000) between the different phases defined by either the time-of-infection or inflammatory marker-based approach and found a significantly higher EMD (two-sided Wilcoxon Rank-sum test, $P$-value $<0.001$ ) for the inflammatory marker approach, indicating a clearer distinction between the different disease phases (Figure 2C).

The median length of the acute-early phase was five (IQR 3-16) and the acute-late phase was eight (IQR 6-16) days (Figure 2D). Sample acquisition for proteomic analysis was performed in accordance with routine procedures between four (IQR 0 19) days before to six (IQR 3-10) days after the inflammation peak as determined by II-6 and CRP expression levels. Post-discharge (recovery) samples for proteomic 
medRxiv preprint doi: https://doi.org/10.1101/2022.03.02.22271106; this version posted March 6, 2022. The copyright holder for this preprint (which was not certified by peer review) is the author/funder, who has granted medRxiv a license to display the preprint in perpetuity. It is made available under a CC-BY-NC-ND 4.0 International license.

analysis were obtained 61 (IQR 38-75) days after the patient surpassed the inflammation peak (Figure 2D \& 2E). C19 patients from all groups entered the hospital five (IQR 3-16) days before and were discharged seven (IQR 5-15) days after the inflammation peak. All patients in need of intensive care during their hospitalization were admitted to the ICU 12 (IQR 3-25) days before and discharged seven (IQR 0-20) days after the inflammation peak. In the majority of C19 patients, mechanical ventilation was initiated four days before the inflammation peak (IQR 2-10) and was terminated in the acute-late phase eight (IQR 4-21) days after the inflammation peak. Twenty-two C19 patients developed a secondary (super)infection (Figure 2A (left)).

A

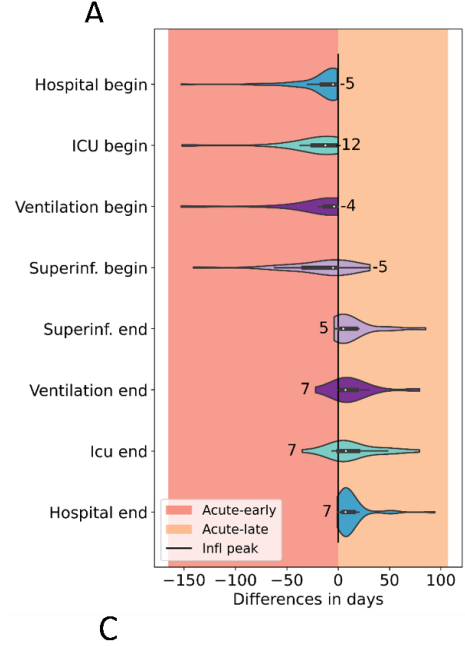

C

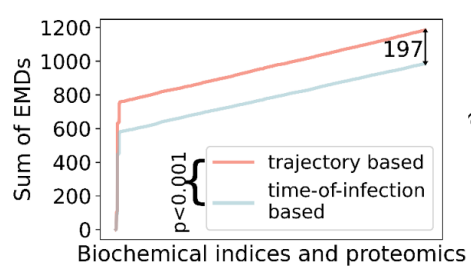

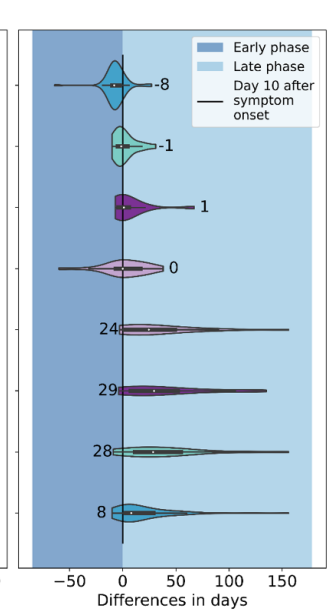

D

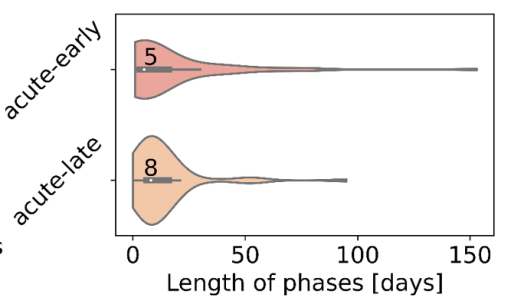

B

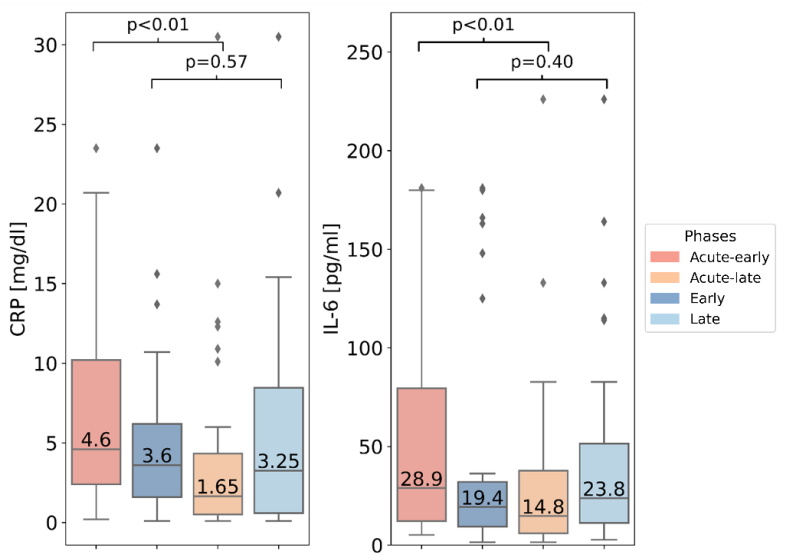

$E$

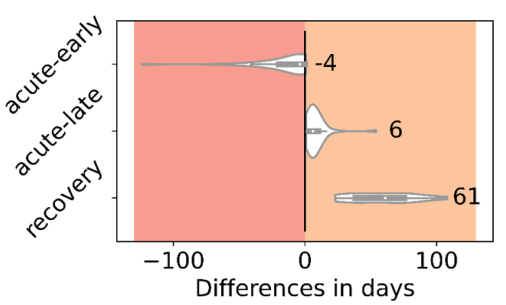

Figure 2: A: Difference in days (median) between critical clinical events and disease phase assignment based on the individual trajectory-based approach (left) and the general time-of-infection-based approach (right). ICU: intensive care unit. B: Distribution of CRP and IL-6 values in different disease phases based on the individual trajectory-based (red) and general time-of-infection-based (blue) approach for disease phase assignment. C: Sum of earth mover's distance $(E M D)$ from routine biochemical indices and proteomic levels comparing the trajectory-based (red) and time-of-infection-based (blue) approach for disease phase assignment. D: Length of disease phases (days; median) on patient level. E: Difference in days (median) between sampling time point and inflammation peak. 
medRxiv preprint doi: https://doi.org/10.1101/2022.03.02.22271106; this version posted March 6, 2022. The copyright holder for this preprint (which was not certified by peer review) is the author/funder, who has granted medRxiv a license to display the preprint in perpetuity. It is made available under a CC-BY-NC-ND 4.0 International license.

\section{Disease-severity and -phase-dependent characteristics of routine laboratory values at admission and in the course of disease}

At the time of admission, C19 patients showed significant changes in routine biochemical indices: Patients assigned to severe disease (C19-ox) showed comparable elevation of neutrophils when compared to the Ctrl-infl group, whereas patients with lower disease grades (C19-nonox) were characterized by blood cell counts within the physiologic range apart from monocytosis (Table S1 \& S2). Whereas CRP levels were found to be significantly different in all other group comparisons, CRP levels were comparable in patients from the C19-ox and Ctrl-infl group together with elevated levels of procalcitonin (PCT) and fibrinogen, thereby indicating the pathologic but non-discriminatory elevation of these parameters in C19-ox patients when compared to patients suffering from inflammation of different origin (Table S1 \& S2). Fibrinogen levels in C19-ox patients showed log2(FC) $=0.42$ higher abundance when compared to the C19-nonox patients. However, ferritin levels were pathologically $\log 2(\mathrm{FC})=1.7(\mathrm{C} 19-\mathrm{ox})$ to $\log 2(\mathrm{FC})=2.5$ (C19-nonox) increased in both $\mathrm{C19}$ severity groups when compared to Ctrl-infl in contrast to lower partial thromboplastin time (PTT, sec) in both C19 disease grades with most pronounced changes in C19-ox (log2(FC)=-0.27, Table S1 \& S2). Reference values for routine laboratory indices are given in Table $\mathbf{S 4}$.

\section{Disease severity dependent differences in routine biochemical indices}

A
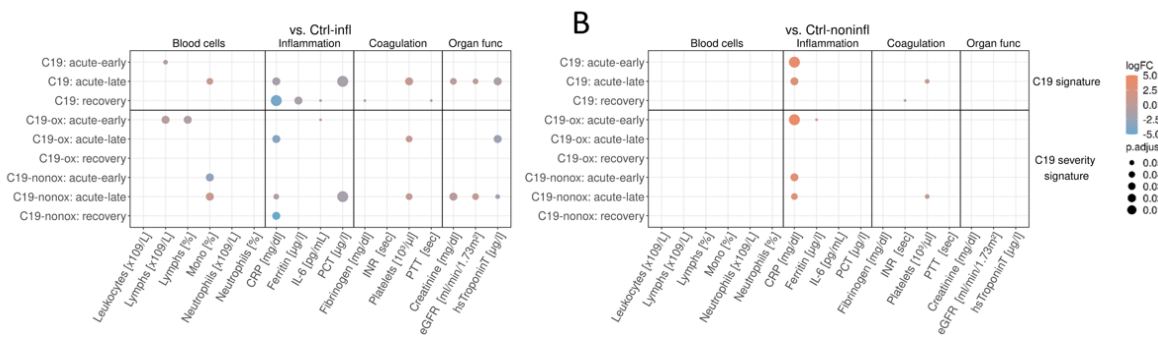

C

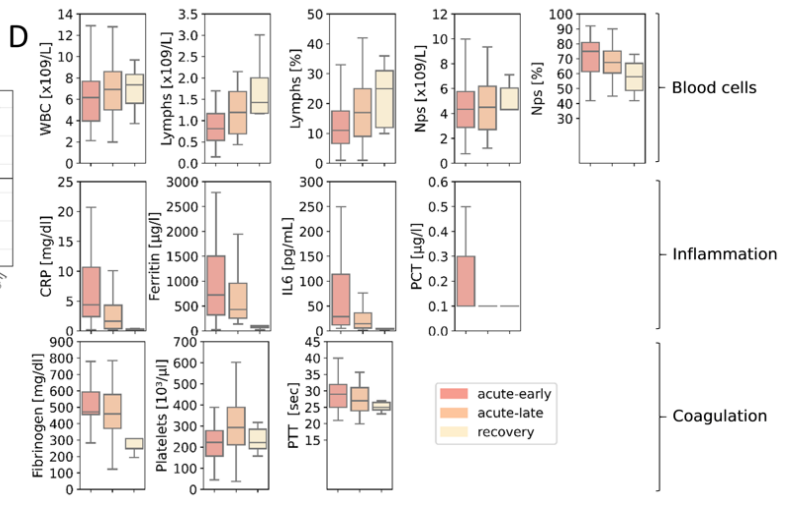


medRxiv preprint doi: https://doi.org/10.1101/2022.03.02.22271106; this version posted March 6, 2022. The copyright holder for this preprint (which was not certified by peer review) is the author/funder, who has granted medRxiv a license to display the preprint in perpetuity. It is made available under a CC-BY-NC-ND 4.0 International license .

Figure 3. Dot plot of routine biochemical indices revealed significant $(P$-value $\leq 0.05)$ differences, describing a general $\mathrm{C} 19$ and a severity-based C19 signature when compared to the Ctrl-infl (A) and Ctrl-noninfl group (B) as well as the trajectory (C). Points represent significant level differences in the respective group comparison, where the color of the dots describes the effect size (log2 fold change) and the size of the dots the significance niveau (adjusted P-value). D: Distribution of selected biochemical indices over the course of the disease.

When investigating the course of the disease, blood cell counts in C19 patients in the acute-early phase of disease were characterized by decreased lymphocyte counts and proportion $\left(\left[\times 10^{9} / \mathrm{L}\right]: \log 2(\mathrm{FC})=-0.69,[\%]: \log 2(\mathrm{FC})=-0.54\right)$ that increased in the acute-late and recovery phase, mainly driven by their downregulation in more diseased patients $\left(\left[\times 10^{9} / \mathrm{L}\right]: \log 2(\mathrm{FC})=-0.51 ;[\%]\right.$ : $\left.\log 2(\mathrm{FC})=-1.0\right)$ when compared with Ctrl-infl (Figure 3A\&C, Figure S2, Table S4). Whereas C19-ox patients in their acute-early and acute-late phase were comparable to the Ctrl-infl group with respect to elevated monocyte proportions, C19-nonox patients showed lower levels in the acute-early phase $(\log 2(\mathrm{FC})=-3.05)$ that increase in the acute-late phase $(\log 2(F C)=0.58)$. Likewise, neutrophil proportions were significantly elevated in $C 19$ patients in the acute-early phase compared to acute-late phase $(\log 2(\mathrm{FC})=0.13)$, with a trend to higher neutrophil levels in more diseased patients in the acute disease phase (acute-early: $\log 2(\mathrm{FC})=0.12$; acute-late: $\log 2(\mathrm{FC})=0.14$ ).

In the acute-late (C19-ox: $\log 2(\mathrm{FC})=-3.54, C 19-$-nonox: $\log 2(\mathrm{FC})=-1.16)$ and recovery phase (C19-ox: $\log 2(\mathrm{FC})=-4.27, C 19-$ nonox: $\log 2(\mathrm{FC})=-4.86)$ CRP levels were lower in both $C 19$ severity groups when compared to the Ctrl-infl group (Figure 3). The overall decline in CRP values in the course of the disease in C19 patients is most pronounced in more diseased individuals to a level of the Ctr-noninfl cohort, whereas in C19-nonox patients moderately elevated CRP levels remain in the acute disease phase and normalize in the recovery phase together with the C19-ox CRP levels (Figure 3D, Table S5\&6). Likewise, IL-6 values were differentially regulated through the course of the disease (Figure 3D, Table S5\&6) with C19-ox patients in their acute-early phase showing significantly higher IL-6 levels $(\log 2(F C)=1.83$, Figure 3C) when compared to C19-nonox patients, in line with recent data (Herold et al, 2020).

Likewise, other inflammation parameters normalized in C19 patients in a disease-severity characteristic manner: While C19-ox patients in their acute-early phase showed elevated PCT levels that were indistinguishable from the Ctrl-infl 
medRxiv preprint doi: https://doi.org/10.1101/2022.03.02.22271106; this version posted March 6, 2022. The copyright holder for this preprint (which was not certified by peer review) is the author/funder, who has granted medRxiv a license to display the preprint in perpetuity. It is made available under a CC-BY-NC-ND 4.0 International license .

group whereas C19-nonox patients did not show elevated levels in the acute-early phase $(\log 2(\mathrm{FC})=1.59 ; \quad$ C19-ox higher). Patients from both severity groups demonstrated normalized levels as compared to Ctrl-noninfl. Additionally, we found a slow normalization of ferritin levels over the course of the disease in all C19 patients (C19: acute-early vs. recovery: $\log 2(\mathrm{FC})=3.03$; $\mathrm{C} 19$ : acute-late vs. recovery: $\log 2(\mathrm{FC})=2.30$ ) (Figure 3C \& D), although ferritin levels still exceeded Ctrl-infl levels up until the acute-late phase (acute-early: $\log 2(\mathrm{FC})=1.42$, acute-late: $\log 2(\mathrm{FC})=0.76$ ) (Figure 3B, Table S5\&6).

Accompanying the inflammatory response, platelet counts showed a physiologic niveau in more severely diseased patients in the acute-early phase to elevated levels exceeding Ctrl-infl levels in the acute-late phase $(\log 2(\mathrm{FC})=0.75)$. In C19-nonox patients, the analysis revealed persistently high and even further increasing platelet counts in the course of the disease when compared to the Ctrl-infl and Ctrl-noninfl groups (Ctrl-infl - acute-early: $\log 2(\mathrm{FC})=0.27$, Ctrl-infl - acute-late: $\log 2(\mathrm{FC})=0.43$ ). Elevated fibrinogen levels in the acute-early and -late phase were observed in both C19 groups compared to Ctrl-noninfl, declining in more diseased patients in the acute-late phase with C19-nonox patients reaching and C19-ox patients reaching close to physiologic levels in the recovery phase (Figure 3C \& D, Figure S2, Table S5). Likewise, elevated PTT levels in C19-ox patients were comparable to Ctrl-infl in acute-early and normalized to physiological levels in the acute-late phase. In C19-nonox patients, moderately higher PTT levels compared to Ctrl-noninfl in acute-early normalized during the acute-late phase (Figure 3, Table S5\&6).

Levels for kidney function, i.e., creatinine levels, and estimated glomerular filtration rate (eGFR) or cardiac injury, i.e., hsTroponinT did only show significant differences in the acute-late phase when compared to Ctrl-infl with creatinine and hsTroponinT reduced (creatinine: $\log 2(F C)=-0.22$, hsTroponinT: $\log 2(F C)=-1.32$ ) and eGFR elevated $(\log 2(F C)=0.29)$ mainly driven by changes in C19-nonox patients (Figure $3 A \&$ C, Figure S2, Table S5 \& 6). 
medRxiv preprint doi: https://doi.org/10.1101/2022.03.02.22271106; this version posted March 6, 2022. The copyright holder for this preprint (which was not certified by peer review) is the author/funder, who has granted medRxiv a license to display the preprint in perpetuity. It is made available under a CC-BY-NC-ND 4.0 International license.

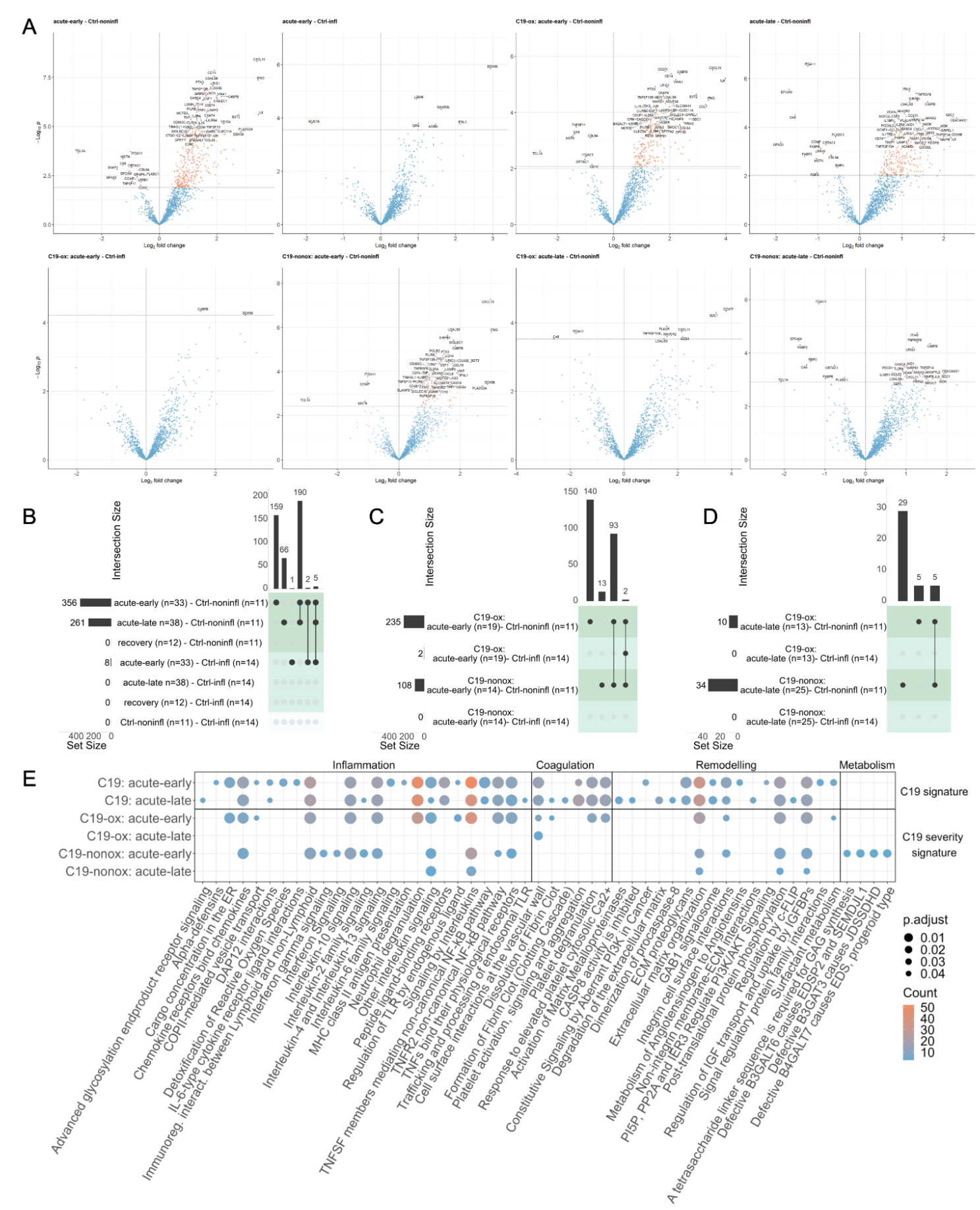

Figure 4: A: Volcano plot of all phase comparisons with Ctrl-noninfl and Ctrl-infl in both severity grades C19-ox and C19-nonox. B: Overlapping significantly differentially abundant proteins in all phase comparisons with Ctrl-noninfl and Ctrl-infl overall; C: between C19-ox and C19-nonox in acute-early phase; D: between C19-ox and C19-nonox in acute-late phase. Horizontal bar graphs indicate total differentially abundant proteins (after multiple testing corrections), while vertical bar graphs indicate the number of overlapping differential proteins between different comparisons. E: Overlap of enriched pathways between all phase comparisons with Ctrl-noninfl. 
medRxiv preprint doi: https://doi.org/10.1101/2022.03.02.22271106; this version posted March 6, 2022. The copyright holder for this preprint (which was not certified by peer review) is the author/funder, who has granted medRxiv a license to display the preprint in perpetuity. It is made available under a CC-BY-NC-ND 4.0 International license.

\section{Proteomic profiling tracking disease indicators for disease stage and severity}

By comprehensively dissecting systemic immune responses at the protein level in C19 patients we significantly added to pathophysiologic insight and enabled the identification of future disease indicators using plasma proteomics obtained on the Olink® Explore platform (see Materials and Methods - Olink plasma proteomics). Disease characterization by these means is outlined in the following chapters.

\section{Type 2 and antiviral immune response in early disease associated with subsequent activation of the coagulation cascade in C19 patients}

The comparison to Ctrl-noninfl patients identified the differential regulation of 356 (acute-early) and 261 (acute-late) proteins in C19 patients irrespective of disease severity. The majority of proteins were found to be upregulated (acute-early: 341; acute-late: 247) and showed a strong overlap of 195 differentially abundant proteins between the disease phases (Figure 4A \& B, Figure 5, Figure S3, Table S7) together with higher absolute log-fold changes in the acute-early comparison (acute-early: 1.0727 [iQR 0.833 - 1.362]; acute-late: 0.9683 [IQR: 0.769- 2.294]). In contrast, the comparison of the recovery phase with Ctrl-noninfl did not reveal significant differences, indicating a normalization of the pathophysiologic changes after discharge in all patients.

Protein regulation in both acute phases was characterized by strong activation of innate and adaptive immune responses including a type-2 immune response, i.e., Interleukin-10 signaling, Interleukin-4, and Interleukin-13 signaling, and TNFR2 non-canonical NF-kB pathway signaling (i.e., TNFs bind their physiological receptors; TNF receptor superfamily (TNFSF) members mediating non-canonical NF-kB pathway), Neutrophil degranulation, DAP12 interactions, Immunoregulatory interactions between a lymphoid and a non-lymphoid cell and GPCR signaling (i.e., Chemokine receptors bind chemokines; Peptide ligand-binding receptors) when compared to Ctrl-noninfl (Figure 4E, Table S8). The inflammation markers LGALS9 (Signaling by Interleukins, Interleukin-2 family signaling) and SIRPB1 (Neutrophil degranulation, Signal regulatory protein family interactions, DAP12 interactions) were significantly upregulated in both acute phases compared to Ctrl-noninfl, next to LRIG1, not represented in any regulated pathway. Interestingly, regulated proteins 
medRxiv preprint doi: https://doi.org/10.1101/2022.03.02.22271106; this version posted March 6, 2022. The copyright holder for this preprint (which was not certified by peer review) is the author/funder, who has granted medRxiv a license to display the preprint in perpetuity. It is made available under a CC-BY-NC-ND 4.0 International license.

such as LGALS9 or SIRPB1 hold matrix remodeling capacities next to immune functions (Hsu et al, 2020; Chen et al, 2019b).

Protein regulation in the acute-early phase was uniquely characterized by the involvement of inflammatory processes including interleukin signaling (i.e., Interleukin-6 family signaling; IL-6-type cytokine receptor-ligand interactions), innate (i.e., Alpha-defensins; Regulation of TLR by endogenous ligand), and adaptive immune responses (i.e., MHC class II antigen presentation), while Interleukin-2 family signaling and innate immune response pathways such as Advanced glycosylation endproduct receptor signaling and Trafficking and processing of endosomal TLR were only significantly regulated in the acute-late phase. The differential regulation between the acute-early and -late phase additionally comprised stress response mechanisms indicated by Detoxification of Reactive Oxygen Species, COPII-mediated vesicle transport, and Cargo concentration in the ER significantly regulated in the acute-early disease phase. The acute-early phase was furthermore characterized by regulation of the top-ranked inflammation marker CXCL10 (log2(FC)>2, Signaling by Interleukins, Interleukin-10 signaling, Chemokine receptors bind chemokines and Peptide ligand-binding receptors), PTX3, involved in Neutrophil degranulation (Daigo et al, 2016), and CD300E (Immunoregulatory interactions between a Lymphoid and a non-Lymphoid cell, DAP12 interactions), all persisting but less pronounced in the acute-late phase irrespective of disease grade. Likewise, IFNG (log2(FC)>2, Signaling by Interleukins), TNFSF13B (TNFs bind their physiological receptors, TNFR2 non-canonical NF-kB pathway, TNF receptor superfamily (TNFSF) members mediating non-canonical NF-kB pathway), and CD14 (Regulation of TLR by endogenous ligand) were predominantly regulated in the acute-early phase in all C19 patients, whereas no differential regulation was observed in the acute-late phase when compared to Ctrl-noninfl. While TNFRSF8 (TNFs bind their physiological receptors, TNFR2 non-canonical NF-kB pathway) and HAVCR2 (Signaling by Interleukins, Interleukin-2 family signaling) were predominantly upregulated in the acute-late phase, their regulation was less pronounced in the acute-early phase when compared to Ctrl-noninfl.

Regulation of coagulation processes could be observed during both acute disease phases when compared to Ctrl-noninfl (i.e., Cell surface interactions at the vascular wall, Platelet activation, signaling and aggregation; Response to elevated platelet 
medRxiv preprint doi: https://doi.org/10.1101/2022.03.02.22271106; this version posted March 6, 2022. The copyright holder for this preprint (which was not certified by peer review) is the author/funder, who has granted medRxiv a license to display the preprint in perpetuity. It is made available under a CC-BY-NC-ND 4.0 International license .

cytosolic Ca2+ and Platelet degranulation), accompanied by the upregulation of the coagulation marker C4BPB, not represented in any pathway, whereas Formation of Fibrin Clot (Clotting Cascade) and Dissolution of Fibrin Clot were significantly regulated in the acute-late phase, together with a downregulation of EPCAM (Cell surface interactions at the vascular wall) and upregulation of ITIH3 (Platelet degranulation, Response to elevated platelet cytosolic Ca2+, Platelet activation, signaling and aggregation), present but less pronounced in the acute-early phase, in line with observations that thrombotic events tend to appear in later disease stages of COVID-19 (Al-Ani et al, 2020; Bussani et al, 2020).

Interestingly, a large proportion of proteins associated with neutrophil activity and NET formation such as ANXA3, CCL7, HSPA1A, LCN2, LGALS9, MMP8, PPIB, PRTN3, and RETN (Wang et al, 2020; Brinkmann et al, 2004) were upregulated in both acute phases (acute-early: 58/78, acute-late: 54/78) compared to Ctrl-noninfl with 36 proteins similarly regulated across both acute disease phases, confirming previous reports of increased NETosis in C19 patients by unbiased proteome screening (Bardoel et al, 2014; Middleton et al, 2020; Nicolai et al, 2020; Zhou et al, 2021; Smet et al, 2021) (Figure 5A). Similarly, the differential regulation of TNF (acute-early: 15/31, acute-late: 11/31) and IL-1 (acute-early: 7/23, acute-late: 7/23) signaling pathway associated proteins were detected in the acute disease phases when compared to Ctrl-noninfl (Figure 5B \& C). The proteins point towards the activation of inflammasome-associated processes (Zheng et al, 2020) which play an important role in NET formation (Münzer et al, 2019, 2021).

Proteins involved in remodeling and repair processes were differentially expressed in both acute disease phases when compared to Ctrl-noninfl as indicated by the regulation of Insulin-like Growth Factor (IGF) transport and uptake by Insulin-like Growth Factor Binding Proteins (IGFBPs), complemented by proteins involved in the Extracellular matrix organization, such as NID1 including regulation of ECM proteoglycans and Integrin cell surface interactions, eGFR signaling (i.e., GAB1 signalosome), and Post-translational protein phosphorylation. Whereas remodeling processes in the acute-early phase were characterized by tissue-cell (Metabolism of Angiotensinogen to Angiotensins; Surfactant metabolism, PI3K/AKT signaling via, i.e., PI5P, PP2A, and IER3) and cell-cell communication and remodeling (i.e., Signal regulatory protein family interactions, i.e., SIRPB1/SFTPA2/SFTPA1/SIRPA), the 
medRxiv preprint doi: https://doi.org/10.1101/2022.03.02.22271106; this version posted March 6, 2022. The copyright holder for this preprint (which was not certified by peer review) is the author/funder, who has granted medRxiv a license to display the preprint in perpetuity. It is made available under a CC-BY-NC-ND 4.0 International license .

protein signature in the acute-late phase was dominated by processes such as the Degradation of the extracellular matrix, Activation of matrix metalloproteinases, Non-integrin membrane-ECM interactions, and regulation of the apoptosis pathways (i.e., CASP8 activity is inhibited, Regulation by c-FLIP, Dimerization of procaspase-8). These processes were accompanied by a decrease in the expression of ITGA11 (Extracellular matrix organization, Integrin cell surface interactions, top-ranked protein in the acute-late phase) and the increased expression of SDC1 (Signaling by Interleukins, Extracellular matrix organization, Other interleukin signaling, Cell surface interactions at the vascular wall). Not represented in the enriched pathways, the metabolic marker CA6 was found to be regulated in the acute-late phase. The downregulation of CA6 is strongly linked to low salivary zinc concentrations, associated with decreased taste acuity (hypogeusia) (Shatzman \& Henkin, 1981), and has been used in the diagnosis of Early Sjögren's Syndrome (Jin et al, 2019).

In summary, the proteomic response of C19 patients during the acute disease phase was characterized by the activation of classical inflammatory pathways, combined with markers indicating activation of the coagulation cascade and matrix remodeling when compared to Ctrl-noninfl individuals (Figures 4 \& 5; Figures S3; Tables S7 \& 8). The unique combination of these processes together with the presence of specific markers, i.e., ANXA3, CCL7, HSPA1A, LCN2, LGALS9, MMP8, PPIB, PRTN3, and RETN pointed towards neutrophil degranulation and neutrophil extracellular trap (NET) formation in the acute disease phases in C19 patients, in line with previous studies describing innate immune cell activation in severe COVID-19 including neutrophil degranulation, NETosis, as well as pro-inflammatory / HLA-DRlo monocyte expansion (Bardoel et al, 2014; Middleton et al, 2020; Nicolai et al, 2020; Zhou et al, 2021; Smet et al, 2021) (Figure 5). In addition, we detected a strong activation of interleukin signaling including activation of TNF signaling and a type-2 inflammation with the potential to counteract TNF-related signaling, especially in monocyte-related functions. These changes occurred together with the activation of both cytotoxic and humoral related immune defense mechanisms related to Interleukin-2 family signaling and DAP-12 in the acute-late phase, indicating the development of an adaptive immune response (Spolski et al, 2018). 
medRxiv preprint doi: https://doi.org/10.1101/2022.03.02.22271106; this version posted March 6, 2022. The copyright holder for this preprint (which was not certified by peer review) is the author/funder, who has granted medRxiv a license to display the preprint in perpetuity. It is made available under a CC-BY-NC-ND 4.0 International license .

Whereas angiotensinogen, surfactant and SIRP metabolism, ROS regulation, and IL-6 signaling dominated protein regulation in the acute-early disease phase, the acute-later course was characterized by the differential expression of proteins indicating matrix degradation and apoptosis (Figure 4E). Pathway enrichment analysis reflected vascular activation and organ damage that persisted into the acute-late phase together with markers of both coagulation and thrombolysis along with platelet degranulation in both acute-early and acute-late disease (Figure 4E). However, protein regulation associated with coagulation processes was more pronounced in the acute-late phase.
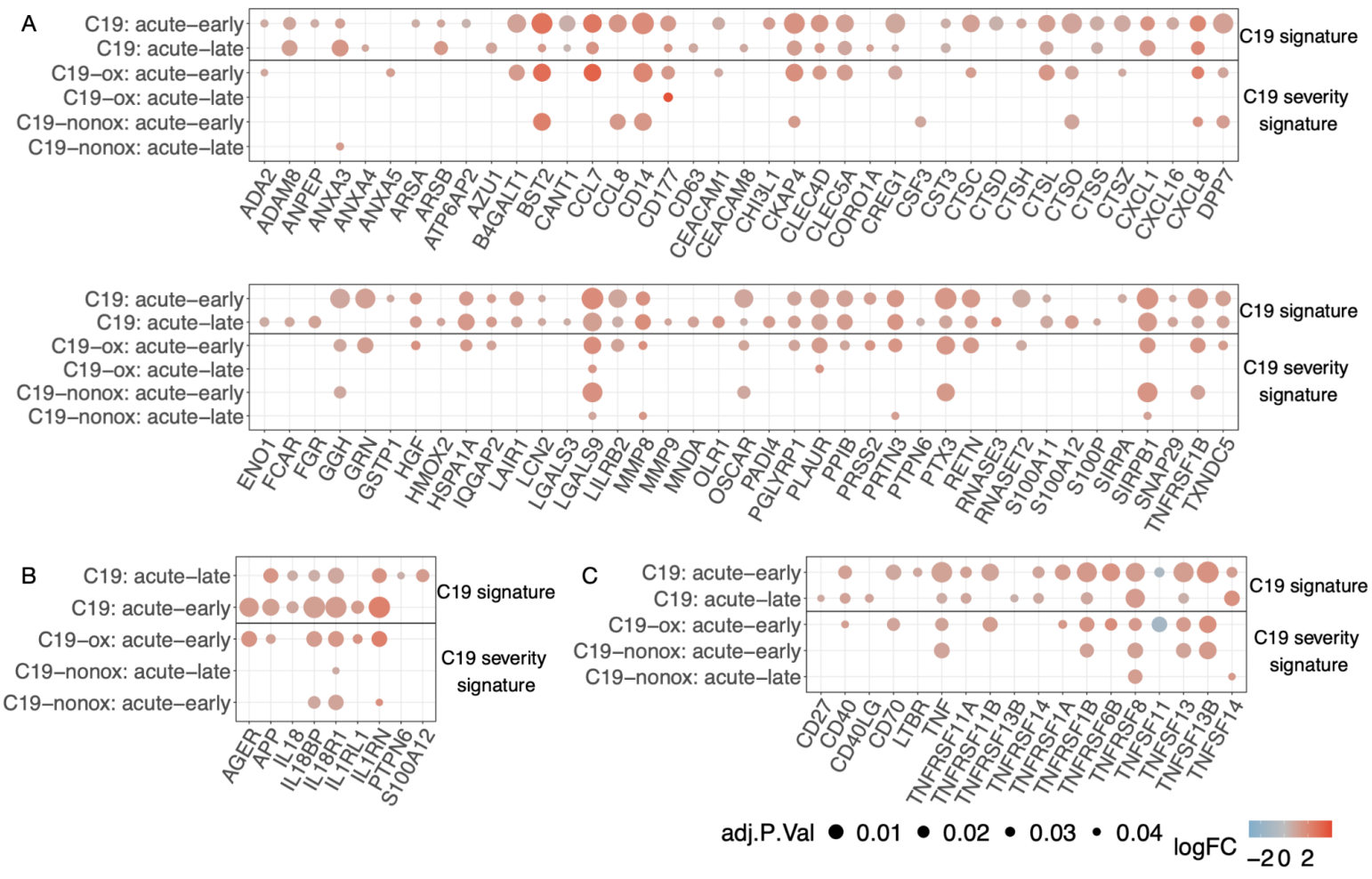

Figure 5: Proteins involved in neutrophil degranulation and (A) NET formation, (B) IL-1 signaling, (C) TNFR cascade in all phase comparisons with Ctrl-noninfl.

\section{Confirmation of the antiviral immune response as a C19-characteristic pattern of protein regulation}

The comparison of C19 patients in the acute disease phases with Ctrl-infl patients demonstrated the differential regulation of eight proteins, all regulated in the acute-early phase irrespective of disease severity, whereas the comparison of the 
medRxiv preprint doi: https://doi.org/10.1101/2022.03.02.22271106; this version posted March 6, 2022. The copyright holder for this preprint (which was not certified by peer review) is the author/funder, who has granted medRxiv a license to display the preprint in perpetuity. It is made available under a CC-BY-NC-ND 4.0 International license .

acute-late phase demonstrated no differentially expressed proteins (Figure 4A \& B, Figure S3, Table S7). The C19-specific profile in the acute-early phase demonstrated the upregulation of antiviral signaling (DDX58, IFNL1, SAMD9L, GRN), lysosomal protein degradation (LGMN, TPP1), and Toll-like receptor signaling (Pišlar et al, 2020), as well as epithelial cell injury through upregulation of AGRN and downregulation of MUC16, as previously described in COVID-19 (Smet et al, 2021) of which a significant proportion was also regulated in the comparison to the Ctrl-noninfl group, i.e., DDX58, SAMD9L, LGMN, TPP1, and AGRN regulated in both acute phases; IFNL1 and GRN regulated in the acute-early phase. However, no coagulation markers or interleukin signaling-associated proteins were found differentially abundant.

The differential regulation of DDX58 (R/G-I) controls the recognition of infected cells while IFNL1 leads to the activation of the JAK/STAT signaling pathway resulting in the expression of IFN-stimulated genes (ISGs). Interestingly, these ISGs mediate the antiviral state essential for containment of SARS-CoV-2 in the upper respiratory tract (Pekayvaz et al, 2021), while loss of ISG function is associated with severe COVID-19 (Bastard et al, 2020; Zhang et al, 2020b). The host response is further characterized by the regulation of apoptosis, cell cycle arrest, and DNA damage through SAMD9L, the activation of defense mechanisms involving monocyte differentiation and MHC class /I presentation through LGMN, lysosomal protease functions controlled by TPP1 and activated through acidification such as GRN that holds a role in inflammation previously associated with COVID-19. Epithelial cell damage was indicated by the regulation of $A G R N$, as part of the lung basal membrane and MUC16, controlling mucus secretion and engaged in epithelial cell replication and apoptosis.

In summary, specific protein regulation in C19 likely related to an activation of the immune system not reflected by routine laboratory variables (i.e., CRP, IL-6, PCT, ferritin, and neutrophil proportions) that did not distinguish C19-ox patients from Ctrl-infl patients. A strong antiviral immune response side-by-side with markers indicating apoptosis and DNA damage both confirm previous findings as well as delineates the $C 19$ immune response in the early course of the disease. 
medRxiv preprint doi: https://doi.org/10.1101/2022.03.02.22271106; this version posted March 6, 2022. The copyright holder for this preprint (which was not certified by peer review) is the author/funder, who has granted medRxiv a license to display the preprint in perpetuity. It is made available under a CC-BY-NC-ND 4.0 International license.

\section{Protein regulation in $\mathrm{C19}$ patients indicates the regulation of antiviral immune} response and a NETosis related activation of the coagulation cascade in more severe disease

When analyzing the general inflammatory response based on the comparison to Ctrl-noninfl cases, the acute-early phase in C19-ox patients revealed 235 significantly regulated proteins, with the majority, i.e., 227 proteins showing a strong upregulation in the acute-early phase in C19-ox patients (Figure 4A \& C, Figure 5,Figure S3, Table S7 \& S8). 140 of these 235 differentially regulated proteins characterized the general inflammatory early response in C19-ox patients and were not found to be differentially abundant within the early response in C19-nonox patients. Specific processes in higher disease severity grades of the acute-early phase involved regulation of the innate immune system via Endogenous ligand TLR signaling and Neutrophil degranulation (supported by an upregulation of the oxygen-specific markers SFTPA2, LBP, GRN, B4GALT1, and RETN in the acute-early phase) as well as stress response regulation indicated by enrichment of the pathways ER to Golgi Anterograde Transport via COPII-mediated vesicle transport and Cargo concentration in the ER. The top 10 of the 140 regulated proteins furtherincluded CCL7 $(\log 2(F C)>2), \quad C C L 2, \quad J U N$, AGER, NDUFS6 $(\log 2(\mathrm{FC})>2)$, indicating the activation of inflammatory and oxidative stress mechanisms in severe disease.

Regulated processes in severely affected C19 patients included both prothrombotic and thrombolytic processes such as Cell surface interactions at the vascular wall, Response to elevated platelet cytosolic Ca2+, Platelet degranulation, and Dissolution of Fibrin Clot. Tissue-cell interaction was represented by Surfactant metabolism, accompanied by the upregulation of the oxygen-specific marker SFTPA2 (also involved in Regulation of TLR by endogenous ligand; top 10) in the acute-early phase. All mentioned pathways apart from Dissolution of Fibrin Clot were found to be regulated in the overall comparison including both severity grades (Figure 4E, Table S8), implying a strong contribution to the inflammatory and prothrombotic phenotype by their upregulation in patients with severe disease.

The acute-late phase in C19-ox patients revealed the differential regulation of ten proteins, eight of which were upregulated (Figure 4A \& D, Figure S4, Table S7 \& S8). Inflammation markers in the acute-late phase of C19-ox patients included the 
medRxiv preprint doi: https://doi.org/10.1101/2022.03.02.22271106; this version posted March 6, 2022. The copyright holder for this preprint (which was not certified by peer review) is the author/funder, who has granted medRxiv a license to display the preprint in perpetuity. It is made available under a CC-BY-NC-ND 4.0 International license .

upregulation of CXCL11 (log2(FC)>2), HAVCR2, TNFRSF10B, SDC1 (log2(FC)>2), and LGALS9, again pointing to a pronounced immune response as well as the activation of remodeling processes.

The coagulation process Cell surface interactions at the vascular wall was found to be persistently regulated in C19-ox patients in the acute-late phase, accompanied by the upregulation of the coagulation marker PLAUR, significantly involved in NET formation (Stavrou et al, 2018). Likewise, involvement of remodeling as well as metabolic processes were indicated by the upregulation of CD177, MZB1, and CA6 (all three with $\log 2(\mathrm{FC})>2$ ), as well as by the downregulation of ITGA11 in these patients. Several proteins, including the activation marker CD177, the thrombolytic PLAUR, as well as proinflammatory factors such as TNFRSF10B, HAVCR2, and MZB1 were uniquely regulated in C19-ox patients during the acute-late phase, in contrast to C19-nonox patients.

The comparison of protein regulation in C19-ox with patients from the Ctrl-infl group revealed the upregulation of DDX58 $(\log 2(\mathrm{FC})>2)$ and C4BPB in the acute-early phase (Figure 4A \& C, Figure S3), whereas the analysis in the acute-late phase did not reveal differentially regulated proteins.

Protein regulation in patients with less severe disease (C19-nonox) revealed 108 differentially expressed proteins in the acute-early phase when compared to Ctrl-noninfl, with an upregulation in the majority of proteins, i.e., 104 (Figure 4A \& C, Figure S3, Table S7 \& S8).

Inflammatory processes in the acute-early phase of C19-nonox patients comprised the enrichment of Interleukin-2 family signaling, Interferon-gamma (), and Interferon signaling (both unique in this comparison) when compared to Ctrl-noninfl. Inflammatory proteins regulated in acute-early C19-nonox, but not in C19-ox comprised the increased abundance of proteins associated with Interleukin-10 signaling (CCL3, CSF3), Chemokine receptors bind chemokines (CCL3, CCL21), and proteins not associated with enriched pathways (CCL8, CLEC6A, VSTM1). Similarly, PDGFRA was only differentially regulated in C19-nonox but not in C19-ox, whereas coagulation activation was not observed by pathway enrichment analysis.

Remodeling processes were indicated by the unique enrichment of pathways in the C19-nonox patients that related to Glycosaminoglycan metabolism (i.e., $A$ 
medRxiv preprint doi: https://doi.org/10.1101/2022.03.02.22271106; this version posted March 6, 2022. The copyright holder for this preprint (which was not certified by peer review) is the author/funder, who has granted medRxiv a license to display the preprint in perpetuity. It is made available under a CC-BY-NC-ND 4.0 International license .

tetrasaccharide linker sequence is required for GAG synthesis; Defective B3GAT3 causes JDSSDHD; Defective B3GALT6 causes EDSP2 and SEMDJL1; Defective B4GALT7 causes EDS, progeroid type). This was accompanied by the downregulation of the remodeling marker COMP(Extracellular matrix organization) as well as by the upregulation of TYMP, C1QTNF1, SCARB2, SIAE, and WISP2, all regulated in acute-early C19-nonox, but not in C19-ox when compared to Ctrl-noninfl. All other significantly enriched pathways in this comparison were shared with the profile observed in the acute-early phase of C19-ox patients (Figure 4E, Table S8). When compared to Ctrl-noninfl, the acute-late phase in C19-nonox patients revealed 34 significantly regulated proteins, 25 of which were upregulated (Figure 4D, Figure S3, Table S7 \& S8). Specifically, 29 of those 34 proteins were regulated in the acute-late phase of C19-nonox patients only, with the top 10 ranked proteins including markers of inflammation (TNFRSF8, LRIG1), coagulation (EPCAM, C4BPB, ITIH3), remodeling (CRTAC1, NID1), and metabolic processes (FABP2, RBP2, CASC4). Pathway enrichment analysis revealed the regulation of inflammatory processes including cytokine signaling via Other interleukin signaling. Remodeling processes in C19-nonox patients during the acute-late phase included Regulation of Insulin-like Growth Factor (IGF) transport and uptake by Insulin-like Growth Factor Binding Proteins (IGFBPs), Post-translational protein phosphorylation, and Extracellular matrix organization.

All differentially expressed pathways in C19-nonox patients that were regulated in the disease independent analysis showed a shared expression with C19-ox patients indicating an equal contribution of both disease severities to the independent comparison in the acute-early disease phase. In contrast, the comparison demonstrated a dominating impact of the C19-nonox patients on the general signature in the acute late phase.

The protein profile in lower disease severity grades showed no differentially regulated proteins when comparing the acute-early and the acute-late phase to the Ctrl-infl group (Figure 4D). Similarly, no differentially regulated proteins could be identified in the recovery phase for both oxygen-dependent and independent patients (Figure 4B). 
medRxiv preprint doi: https://doi.org/10.1101/2022.03.02.22271106; this version posted March 6, 2022. The copyright holder for this preprint (which was not certified by peer review) is the author/funder, who has granted medRxiv a license to display the preprint in perpetuity.

In summary, processes identified in C19 patients in general as outlined above were found to be more prominently or solely regulated in severely diseased C19 patients. When comparing severity groups, these changes were accompanied by a strong induction of an innate immune response in the early-acute phase indicated by Regulation of TLR through endogenous ligands, Neutrophil degranulation, and stress response mechanisms with Cargo concentration in the ER, and COPII-mediated vesicle transport. Simultaneously, procoagulant and thrombolytic phenomena, i.e., Response to elevated platelet cytosolic calcium, Platelet degranulation, Response to elevated platelet cytosolic Ca2+, Cell surface interactions at the vascular wall, and Dissolution of Fibrin Clot, could be observed in C19-ox patients (Figure 4E).

In contrast, protein regulation in less severely diseased $C 19$ patients was dominated by a general inflammatory response exemplified by the group-specific regulation of interleukin-2 and IFNG signaling in the acute-early phase, as well as a shared pattern, i.e., regulated in both severity groups that included remodeling processes indicated by regulation of Extracellular matrix organization, Post-translational protein phosphorylation, and Regulation of Insulin-like Growth Factor transport and uptake by Insulin-like Growth Factor Binding Proteins in the acute-early and -late phase (Figure 4E). Interestingly, no pathways or proteins directly related to coagulation were found to be significantly regulated in less diseased patients, confirming previous clinical observations in these patients (Nicolai et al, 2020).

Changes observed in routine laboratory variables were reflected in protein expression patterns, i.e., elevated neutrophil numbers in more diseased patients correlated with the increased presence of markers for neutrophil degranulation and coagulation.

\section{Dynamic regulation of immune and remodeling processes in the course of disease depending on disease severity}

Next, we investigated the disease phase-dependent regulation of plasma proteins in C19 patients. Changes over the entire disease trajectory revealed 45 inflammation markers, four coagulation markers, 20 markers indicating remodeling processes, and 19 metabolic markers to be differentially regulated (Figure 6A, Figure S3, Table S9 \& S10). 
medRxiv preprint doi: https://doi.org/10.1101/2022.03.02.22271106; this version posted March 6, 2022. The copyright holder for this preprint (which was not certified by peer review) is the author/funder, who has granted medRxiv a license to display the preprint in perpetuity. It is made available under a CC-BY-NC-ND 4.0 International license .

Specifically, 33 proteins were found to be differentially abundant between the acute-early and acute-late phase, yielding significant differences in interleukin signaling (Figure 6A \& B \& E \& F, Figure S3). As expected, 17 of those 33 proteins showed strong differences between the acute-early and acute-late phase when compared to Ctrl-noninfl. Here, CD14, IFNG, TNFSF13B, CTSO, ANGPTL1, GRN, C1QA, AGER, IFNL1, LAG3, HLA-E, CCL8, GAS6, IL4R, CTSZ, and PLA2G15 were upregulated in the acute-early phase when compared to Ctrl-noninfl but were not significantly regulated in later phases, indicating an innate immune host response that involves vascular and matrix remodeling specific proteins and prominent interferon-related signaling in the acute-early disease phase. In contrast, PADI4 was only upregulated in the acute-late phase when compared to Ctrl-noninfl, holding a critical role in granulocyte and macrophage-dependent immune responses and a critical role in NET formation (Liu et al, 2021). Upregulation of LGALS9, LRIG1, CXCL10, SIGLEC1, CD300C, and TCN2 in both acute phases compared to Ctrl-noninfl with significantly higher expression levels in the acute-early phase than in the acute-late phase pointed towards an innate immune response while involving factors that contribute to NET formation as well as stroke risk.

GLB1, OXT $(\log 2(F C)>2)$, FGF21, IL34, BAG3, SEMA4C, TLR3, GPR37, ANXA5 were found to be significantly upregulated in the $\mathrm{C} 19$ intragroup comparison of disease phases, i.e., during the acute-early disease course, whereas NCF2 was upregulated in the acute-late phase.

When comparing the acute-early to the recovery phase, we identified 59 differentially regulated proteins involved in innate and adaptive immunity, as well as remodeling processes with a predominant upregulation in the acute-early phase. The top 10 regulated proteins reflected this by the inclusion of inflammatory (CD300E, IL15, IFNG, LGALS9, CD14, CXCL10, IFNGR2, LILRB4), metabolic (CASC4), and remodeling processes (CDON9). Downregulated proteins were engaged in immune response mechanisms including cell adhesion, adaptive immune processes, cell-cell matrix interaction, and related metabolic activity (CD1C, TNFSF11, SELPLG, SKAP1 (inflammation), CDON, THBS4, MFAP5 (remodeling), PLTP (metabolism)) (Figure

\section{A \& B, Figure S3).}

Between the acute-late and the recovery phase, 17 proteins were found to be differentially regulated including inflammatory (BST2 $(\log 2(F C)>2)$, SDC1, DDX58, 
medRxiv preprint doi: https://doi.org/10.1101/2022.03.02.22271106; this version posted March 6, 2022. The copyright holder for this preprint (which was not certified by peer review) is the author/funder, who has granted medRxiv a license to display the preprint in perpetuity. It is made available under a CC-BY-NC-ND 4.0 International license .

LGALS9, LILRB4), and coagulation specific (C4BPB, ITIH3) processes together with Remodeling of cardiac muscle and blood vessels (CDH2, SMOC1) and other tissues (GFRA1, MDK, BAIAP2, SMOC1), and metabolic activity (CASC4, MME, FKBP5). Whereas these proteins were upregulated in the acute-late phase, the proteins ITGA11 and ROBO2 with a role in tissue remodeling were upregulated in the recovery phase (Figure $\mathbf{6 A} \& \mathbf{B}$, bottom left circle). It has to be noted that important proteins such as BAIAP2 and GFRA1 that were identified by the phase comparison hold critical functions in the central nervous system.

While the majority of proteins, especially those associated with coagulation, showed a constant decrease in abundance over the disease trajectory, some proteins increased over time, e.g., CD1C, SELPLG (inflammation), SKAP1, TNFSF11 (inflammation), PLTP (metabolism), CDON, and MFAP5 (remodeling). Other proteins displayed more complex regulation patterns such as delayed changes, e.g., ITGA11, ROBO2, and THBS4 remained unchanged in acute disease and increased in recovery phase, while ANGPTL1 and FGF21 decreased in the acute-late and FKBP5 in the recovery phase; or alternating patterns (e.g., PADI4, SDC1, and BAIAP2) (Figure S4\&S5).

When comparing disease phase-specific regulation for both severity grades, disease phase-dependent regulation differed for C19-ox and C19-nonox patients in the acute-late phase of the disease. Here, the comparison showed an upregulation of 14 proteins in C19-ox patients indicating the activation of innate and adaptive immune response mechanisms, energy metabolism, stress response, and remodeling including modulation of growth factor signaling (CRNN, FOLR1, PAG1 (inflammation), CD177 (log2(FC)>2), HK2, MSLN, NOS1, SFTPA2, SRP14, TNFRSF10B (remodeling), PFKFB2, WFDC2, RASSF2, REG1A (metabolism)) (Figure 6A \& C, Figure S3). No phase-specific regulated protein could be identified in C19-ox patients, while lower disease grades demonstrated differential regulation such as the upregulation of OXT ( $\log 2(\mathrm{FC})>2$, metabolism) in the acute-early phase when compared to the acute-late phase together with the inflammatory markers IFNL1, IL6, BST2 (all log2(FC)>2), CD300E, LGALS9, and LILRB4 in comparison to the recovery phase. Additionally, coagulation and complement activation, e.g., upregulation of ITIH3 (coagulation) and C4BPB (coagulation) were observed in the 
medRxiv preprint doi: https://doi.org/10.1101/2022.03.02.22271106; this version posted March 6, 2022. The copyright holder for this preprint (which was not certified by peer review) is the author/funder, who has granted medRxiv a license to display the preprint in perpetuity. It is made available under a CC-BY-NC-ND 4.0 International license.

acute-late phase when compared to the recovery phase. (Figure 6A \& D, Figure S3).

Disease trajectory regulated inflammation associated pathways were primarily observed between acute-early and recovery phases, including interleukin signaling (i.e., Interleukin-10 signaling), Neutrophil degranulation, Cargo concentration in the $E R$, and Immunoregulatory interactions between a Lymphoid and a non-Lymphoid cell, capturing the innate and adaptive immune system, as well as ROS regulation. Remodeling processes further characterize the comparison between acute-early and recovery phase and comprised the Regulation of Insulin-like Growth Factor transport and uptake by Insulin-like Growth Factor Binding Proteins, as well as Post-translational protein phosphorylation via Transport to the Golgi and subsequent modification. Transport to the Golgi and subsequent modification was uniquely regulated in this comparison (Figure 6F).

For proteins contributing to NET formation, a gradual decrease was detected over time for CCL8, LGALS9, ANXA5, GRN, CTSC, and MME when comparing the acute-early phase to later stages, whereas PADI4 and NCF2 showed an increase in the acute-late phase (Figure S4), implicating neutrophil hyperactivation following the inflammatory peak.

In summary, the acute-early disease phase is specifically characterized by an innate immune, virus-related host response that involves vascular and matrix remodeling, while matrix remodeling proteins were also found to be upregulated in the recovery phase when compared to the acute-late phase (Figure 6A \& B \& E \& F, Figure S3). In contrast, the critical regulator of NET formation PADI4 was differentially regulated in the acute-late phase. Protein expression pattern in both acute phases indicated regulation of innate immune defense mechanisms such as activation and recruitment of leukocytes, autophagy and indicated by the regulation of CXCL10, SIGLEC1, CD300C, NCF2, ANAX5, and BAG3 and matrix remodeling as identified through the differential expression of SEMA4, LGALS9, and GLB1, promoting mesenchymal activation and matrix formation. Interestingly, TCN2, engaged in vitamin B12 uptake, has been described to modify stroke risk (Hsu et al, 2011), whereas GPR37 signaling has been shown to modulate the migration of olfactory ensheathing cells (Saadi et al, 2019). This expression pattern was most prominent in C19-ox patients who 
medRxiv preprint doi: https://doi.org/10.1101/2022.03.02.22271106; this version posted March 6, 2022. The copyright holder for this preprint (which was not certified by peer review) is the author/funder, who has granted medRxiv a license to display the preprint in perpetuity. It is made available under a CC-BY-NC-ND 4.0 International license.

showed a strong time-dependent regulation of innate, adaptive immune, and stress response, as well as activation of the coagulation and complement system, e.g., upregulation of ITIH3 (coagulation) and C4BPB (coagulation), in the acute-late phase when compared against the recovery phase (Figure 6A \& C \& D, Figure S3).

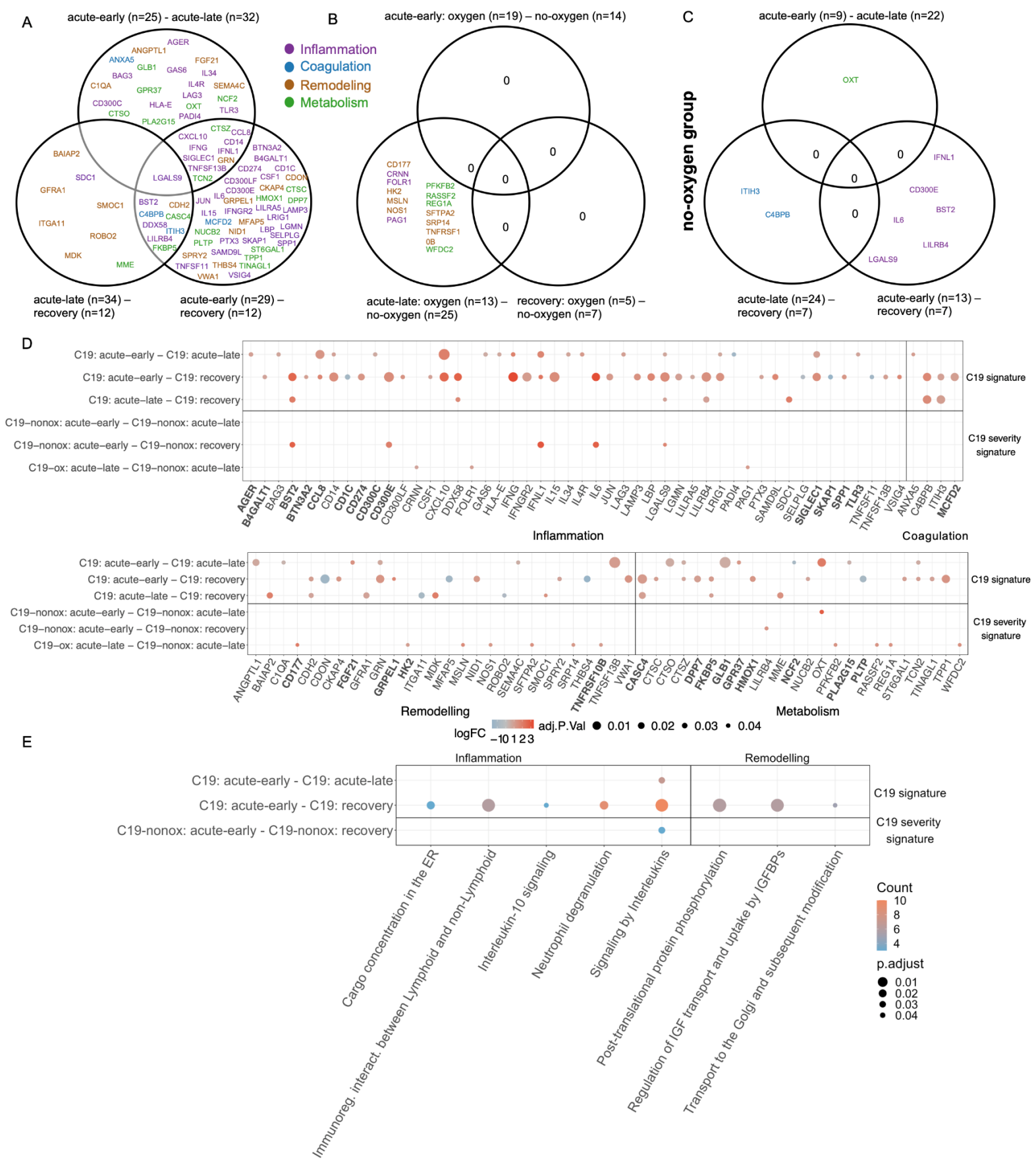

Figure 6: A: COVID-19 phase-dependant differential regulation of plasma proteins and their intersections. B: Differentially regulated plasma proteins and their intersections for disease severity 
medRxiv preprint doi: https://doi.org/10.1101/2022.03.02.22271106; this version posted March 6,2022 . The copyright holder for this preprint
(which was not certified by peer review) is the author/funder, who has granted medRxiv a license to display the preprint in perpetuity. It is made available under a CC-BY-NC-ND 4.0 International license.

comparisons (C19-ox/C19-nonox) considering different disease phases; purple: inflammation; blue: coagulation; brown: remodeling; green: metabolism C: Intersections of differentially abundant plasma proteins for different disease phases in C19-nonox. D: Log2 fold-change of phase-regulated proteins. Protein symbols in bold are associated with NETosis, IL-1, or TNF signaling. E: Overlapping pathways of all disease phase comparisons.

\section{Discussion}

Although to date, numerous studies have described the wide range of symptoms of severe SARS-CoV-2 infection, e.g., acute respiratory distress syndrome (ARDS), lymphopenia, coagulopathy, and multi-organ damage (Bernardes et al, 2020; Faust et al, 2020; Wiersinga et al, 2020), a detailed analysis of the underlying sequence of events is still missing. Studies that targeted protein regulation in COVID-19 patients aimed for a better understanding of disease-related processes while trying to identify potential biomarkers at the same time and have reported different immune response-related phenomena. The so-called "cytokine storm" comprised regulation of CXCL8, CXCL10, IL-6, TNFalpha, and IFNG, indicating that the synergism between TNF- $\alpha$ and IFNG, known to trigger inflammatory cell death and tissue damage, may account for SARS-CoV-2 mortality due to cytokine shock (Karki et al, 2021; Buszko et al, 2021; Yang et al, 2021) and potentially addressed by existing therapies (Tang et al, 2020).

Our study addressed the gap of existing knowledge with regard to a differentiated understanding of disease dynamics while specifically considering disease stage and severity, thereby significantly adding to existing knowledge in the field (Figure 7). Rooting the protein markers detected by an unbiased approach in disease pathophysiology, we achieved the identification of critical disease-stage and -phase-specific indicators in high-risk COVID-19 patients. We both confirmed as well as newly discovered urgently needed markers in a COVID-19 patient population that is omnipresent in university hospitals due to diverse preexisting conditions. 
medRxiv preprint doi: https://doi.org/10.1101/2022.03.02.22271106; this version posted March 6, 2022. The copyright holder for this preprint (which was not certified by peer review) is the author/funder, who has granted medRxiv a license to display the preprint in perpetuity. It is made available under a CC-BY-NC-ND 4.0 International license.

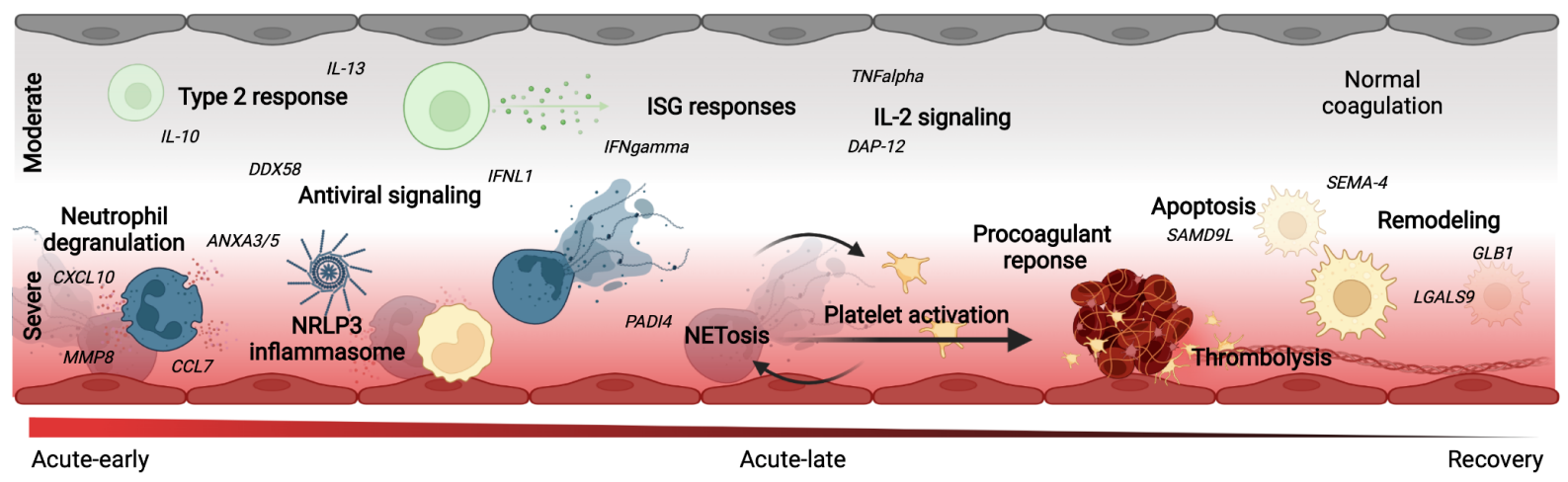

Figure 7: Schematic overview of the disease-phase and disease-severity-dependent pathophysiologic response in moderate (WHO $\leq 4$, upper half, C19-nonox) and severe (WHO $\geq 4$, lower half, C19-ox) C19 patients. While sharing a significant pattern of protein regulation, i.e., TNF signaling, severe disease was characterized by antiviral- and NETosis-related protein regulation including coagulation activation. Moderate disease associated patterns were dominated by a type-2 immune response and IL-2 associated signaling. Both disease severity grades progress from acute inflammation to the activation of remodeling processes.

To relate the plasma protein signatures detected by proteome screening to clinically relevant disease phases while considering internationally accepted disease severity grades, we studied COVID-19 patients in comparison to both non-inflammatory and inflammatory control subjects. To sensitively address the heterogeneous disease characteristics in a multimorbid patient cohort, we improved disease phase assignment by defining novel individual clinical trajectories using the inflammation markers IL-6 [pg/ml] and CRP [mg/dl]. In contrast to our approach, previous SARS-CoV-2 studies solely relied on disease phase assignment relating to the number of days after symptom onset, PCR result, or hospital admission, while other studies primarily referred to disease symptomatology (Schulte-Schrepping et al, 2020; Lam et al, 2021). In general, cutoffs of inflammation markers have been used with good success in predicting COVID-19 severity at admission (Herold et al, 2020) but did not consider individual trajectories and threshold of laboratory variables that are likely of importance when studying a cohort with significant preexisting conditions and related medications.

The significant variation in the course of the disease when comparing different patient groups and treatment settings (Tolossa et al, 2021), including the average time for symptom resolution (2 to 71 days (Abrahim et al, 2020) or 10-14 (mild disease) to 21-42 (severe disease) days (Bhapkar et al, 2020; Jin et al, 2020)), likely renders solely 'time-after-infection' based disease phase assignment inaccurate, 
medRxiv preprint doi: https://doi.org/10.1101/2022.03.02.22271106; this version posted March 6, 2022. The copyright holder for this preprint (which was not certified by peer review) is the author/funder, who has granted medRxiv a license to display the preprint in perpetuity. It is made available under a CC-BY-NC-ND 4.0 International license .

especially in patients with multiple influencing factors. In contrast to previous approaches (Schulte-Schrepping et al, 2020), we, however, demonstrated that the trajectories based on the individual course of critical routine laboratory markers, more adequately matched clinical symptoms and critical events in the patient cohort studied, resulting in better discriminatory power for (severity-dependent) disease phase separation.

We showed that the inflammatory response in $C 19$ patients obtained by the comparison to healthy individuals is characterized by a strong induction of innate immune response mechanisms in the early-acute phase as indicated by the regulation of TLR through endogenous ligands, Neutrophil degranulation together with cargo concentration in the ER, and COPll-mediated vesicle transport accompanied by the parallel upregulation of prothrombotic and thrombolytic phenomena, i.e., Dissolution of Fibrin Clot, Response to elevated platelet cytosolic calcium, and Platelet degranulation. The significant overlap of this protein signature with the disease-specific response revealed by the comparison to patients with signs of non-SARS-CoV-2 related inflammation the importance of interferon related antiviral signaling, i.e., DDX58 as confirmed by previous studies (Winheim et al, 2021), together with the regulation of apoptosis and DNA damage, accompanied by the activation of TLR signaling, lysosomal functions and an indication of epithelial cell damage.

This response could be largely attributed to severe disease, whereas protein regulation in mild-to-moderately affected C19 patients was dominated by the disease-stage specific regulation of interleukin-2 and INFG signaling, as well as the shared regulation of remodeling processes as indicated by the regulation of Extracellular matrix organization, Post-translational protein phosphorylation, and Regulation of Insulin-like Growth Factor transport and uptake by Insulin-like Growth Factor Binding Proteins in the acute-early and late phase. However, the differential regulation indicated no activation of coagulation processes in less diseased patients in comparison to the Ctr-noninfl group although anticoagulation treatments were equally administered in both groups (C19-nonox: 62.16\%, C19-ox: 59.26\%). Interpretation of these findings, however, needs to take into account that deaths in 
medRxiv preprint doi: https://doi.org/10.1101/2022.03.02.22271106; this version posted March 6, 2022. The copyright holder for this preprint (which was not certified by peer review) is the author/funder, who has granted medRxiv a license to display the preprint in perpetuity. It is made available under a CC-BY-NC-ND 4.0 International license .

the C19-ox group resulted in the overrepresentation of survival-related changes to protein expression in later disease phases.

The strong upregulation of proteins related to NET formation (Wang et al, 2020; Brinkmann et al, 2004) was observed during both acute COVID phases (acute-early: 58/78, acute-late: 54/78) with 36 proteins similarly regulated. Activation of NET formation in context with other indicators of inflammasome activation (Bardoel et al, 2014; Middleton et al, 2020; Nicolai et al, 2020; Zheng et al, 2020; Zhou et al, 2021; Smet et al, 2021) specifically characterized patients with severe disease (WHO >= 4). The regulated proteins included CD177, a prominent activation marker present on the surface of circulating neutrophils (Nicolai et al, 2020; Bai et al, 2017), MME (CD10) as an immaturity marker of neutrophils and previously associated with severe COVID-19 (Schulte-Schrepping et al, 2020; Kaiser et al, 2021), PDGFRA as a marker of platelet degranulation, and PADI4 as a key regulator of NETosis, whereas the classical NETosis/degranulation marker MPO was not found to be regulated in any of the comparisons. Similarly, strong activation of inflammasome related processes was indicated by the regulation of AGER as an important regulator of CASP-11 inflammasome activation (Chen et al, 2019a) side-by-side with an upregulation of IL-1 and IL-18 (Zheng et al, 2020), as well as IL-6 and TNF expression together with an overenrichement of TNF receptor superfamily (TNFSF) members mediating non-canonical NF-kB pathway (Zheng et al, 2020). Regulation of PLAUR points towards thromboembolic phenomena in these patients (Nicolai et al, 2020; Schulte-Schrepping et al, 2020; Wilk et al, 2020), which were controversially discussed for their dependence on disease severity (Nicolai et al, 2020).

When tracking the disease course, we observed the differential regulation of protein expression related to angiotensinogen, surfactant and SIRP metabolism, ROS regulation, and IL-6 signaling during early disease in the overall comparison and especially in the C19-ox patients in comparison to the non-inflammatory control group, whereas the later phase is characterized by the predominant regulation of proteins associated with matrix degradation and apoptosis.

On the one hand, we hereby show regulation of significant players in the immune host response confirming the role of inflammatory cell death and tissue damage (Karki et al, 2021). On the other hand, we were able to add to previous studies by showing the dynamic of NETosis and inflammasome regulation (Bardoel et al, 2014; 
medRxiv preprint doi: https://doi.org/10.1101/2022.03.02.22271106; this version posted March 6, 2022. The copyright holder for this preprint (which was not certified by peer review) is the author/funder, who has granted medRxiv a license to display the preprint in perpetuity. It is made available under a CC-BY-NC-ND 4.0 International license.

Middleton et al, 2020; Nicolai et al, 2020; Zhou et al, 2021; Smet et al, 2021) in severely affected patients in contrast to a type-2 centered immune response involving interleukin 4, 10,13, and TNF signaling in both disease groups or in less severe disease only (e.g., Interleukin-2 family and IN signaling). These changes were found to be accompanied by remodeling processes.

Activation of the coagulation system was primarily detected in severely diseased patients in our cohort, although clinical reports also detected thromboembolic events in less severe disease (Chen et al, 2021; Clavijo et al, 2021), potentially due to the lack of detection regarding local, organ-specific events. Activation of the coagulation system in more severely diseased patients, as well as activation of the complement system likely drives thrombo-inflammation in COVID-19 (Afzali et al. 2021).

Regulation of proteins such as CA6 (associated with hypogeusia) or TCN2 (associated with stroke) identify disease characteristics, thereby supporting the significant potential of our unbiased approach to inform both pathophysiologic understanding and biomarker development.

Previous studies that employed proteome analysis mirrored our findings such as activation of the complement system, monocyte signaling (CD14, proteins of the LGAL family) and inflammation (CD48, SIRPB1) (Park et al, 2020), as well as the regulation of different plasma protease inhibitors such as ITIH3 (Geyer et al, 2021; Messner et al, 2020; Park et al, 2020; Shen et al, 2020) in COVID-19. Further in line with our findings, vascular markers such as VWF and proteins indicating coagulation activation were found to be regulated in previous studies, but in contrast to our studies described an early decrease (Messner et al, 2020; Shen et al, 2020). Likewise, proteins involved in metabolic processes such as lipoprotein homeostasis (PLTP) were differentially regulated in COVID-19 patients.

Enabling us to put the proteomic signatures into perspective and validate disease phase assignment, we comprehensively tracked biochemical indices. Here, comparable changes were observed in C19-ox and non-C19 related inflammation (Ctrl-infl) patients including, despite its common use in SARS-CoV2 (Liu et al, 2020a), nondiscriminatory CRP levels when comparing C19-ox patients with subjects suffering from non-COVID related inflammation. Proteomic analysis, 
medRxiv preprint doi: https://doi.org/10.1101/2022.03.02.22271106; this version posted March 6, 2022. The copyright holder for this preprint (which was not certified by peer review) is the author/funder, who has granted medRxiv a license to display the preprint in perpetuity. It is made available under a CC-BY-NC-ND 4.0 International license .

however, significantly broadened the picture by demonstrating significant differences in protein expression between these groups. In contrast, PTT levels differed between C19-ox and Ctrl-infl patients, in line with the observed proteomic pattern indicating coagulation activation in C19-ox patients. Although shortened PTT times were discussed to predict poor outcome in patients with varying diseases (Reddy et al, 1999), its role in COVID-19 is still controversially discussed (Devreese, 2021).

Changes in proteome pattern during the course of disease in each severity group were mirrored by cell numbers as well as coagulation and inflammation markers.

Regarding differential blood counts, the analysis in C19-ox patients indicated lymphopenia, low monocyte levels, and neutrophilia when compared to C19-nonox patients, in line with previous studies (Huang et al, 2020; Williamson et al, 2020; Lombardi et al, 2020) but again did not differentiate well severely affected patients from subjects with inflammation of different origin (Ctrl-infl) supporting the controversial discussion of their predictive value (Woodruff et al, 2020). In context with the changes in differentiated blood cell counts, the proteome changes likely reflected the activation of the immune system and again indicated the added value in delineating COVID-19 immune responses in relation to disease severity and -phase (Figure 3 \& 4). Lower monocyte levels in more severely affected patients, however, could relate to the extravasation of these cells and suggest the subsequent activation of macrophages as indicated by the observed proteomic signature (Arango Duque \& Descoteaux, 2014).

Association of INFG and TNF-associated monocyte polarization and the pro-fibrotic potential of monocyte-derived alveolar macrophages underline the potential of the observed signature to induce long-term remodeling (Castro et al, 2018; Misharin et al, 2017).

With regard to the impact of (co)morbidities, previous studies identified risk factors that were in part reflected in our cohort. Whereas C19-ox patients were characterized by increased age when compared to C19-nonox patients in line with previous studies (Huang et al, 2020; Williamson et al, 2020), we could not observe a higher rate of male patients in more severe disease (Huang et al, 2020; Williamson et al, 2020). Similarly, we did not observe a significantly reduced time between symptom onset and hospitalization for more diseased patients (Liu et al, 2020b; 
medRxiv preprint doi: https://doi.org/10.1101/2022.03.02.22271106; this version posted March 6, 2022. The copyright holder for this preprint (which was not certified by peer review) is the author/funder, who has granted medRxiv a license to display the preprint in perpetuity. It is made available under a CC-BY-NC-ND 4.0 International license .

Zhou et al, 2020), but confirmed a longer hospital stay (Liu et al, 2020b; Zhou et al, 2020), higher rates for ICU admission (Liu et al, 2020b; Zhou et al, 2020; Grasselli et al, 2020), invasive ventilation (Liu et al, 2020b; Zhou et al, 2020), and adverse outcome. Further, we demonstrated a higher incidence of comorbidities, e.g., pre-existing lung disease, e.g., COPD or asthma (Huang et al, 2020; Williamson et al, 2020), hypertension (Huang et al, 2020; Williamson et al, 2020), diabetes (Huang et al, 2020; Williamson et al, 2020), kidney diseases (Williamson et al, 2020), or impaired immune function (Huang et al, 2020; Williamson et al, 2020) in more diseases patients (C19-ox). In contrast, we did not find disease symptoms more prevalent in C19-ox patients compared to C19-nonox patients with the exception of fatigue, dyspnea, and an increased incidence in secondary infections, in line with previous studies (Liu et al, 2020b; Zhou et al, 2020) and in part explaining the increased duration in hospital stay.

Limitations of the present study include its observational design and the retrospective analysis resulting in missing data in a small number of patients. Partially counteracting these imitations, the study benefits from homogenous and comprehensive clinical monitoring in a high-risk patient collective that continuously dominates patient admission in university hospitals during the COVID pandemic. While providing a very good basis for biomarker identification in different disease phases and severity grades, results have to be confirmed in targeted approaches in different clinical centers. These prospective studies need to include - amongst others - environmental or social factors not investigated in the current study while considering the impact of emerging SARS-CoV-2 variants and the effect of the potentially gender-dependent vaccination status, not present in the first pandemic wave addressed in our approach (Ovies et al, 2021).

In summary, we identified a COVID-related protein signature that indicates an antiviral response together with NET / inflammasome activation predominantly driven by their regulation in severely affected patients. In contrast, regulation in less severely diseased patients was found to be characterized by a type-2 centered immune response. The findings were enabled by the newly identified disease trajectories based on the individual course of important routine laboratory variables. 
medRxiv preprint doi: https://doi.org/10.1101/2022.03.02.22271106; this version posted March 6, 2022. The copyright holder for this preprint (which was not certified by peer review) is the author/funder, who has granted medRxiv a license to display the preprint in perpetuity. It is made available under a CC-BY-NC-ND 4.0 International license.

This approach both confirms findings from previous studies and also facilitates the identification of new proteins with significant potential to serve as COVID-19 disease indicators at the same time. 
medRxiv preprint doi: https://doi.org/10.1101/2022.03.02.22271106; this version posted March 6, 2022. The copyright holder for this preprint (which was not certified by peer review) is the author/funder, who has granted medRxiv a license to display the preprint in perpetuity.

\section{Materials and Methods}

Table 1: Group and phase definitions as well as study overview.

\begin{tabular}{|c|c|}
\hline Study groups & Description \\
\hline COVID-19 (C19; n=64) & PCR positive SARS-CoV-2 infection \\
\hline C19 oxygen group (C19-ox; n=27) & $\begin{array}{l}\text { PCR positive SARS-CoV-2 infection; } \\
\text { oxygen supply due to COVID-19: WHO score 4-8 }\end{array}$ \\
\hline $\begin{array}{l}\text { C19 no-oxygen group (C19-nonox; } \\
n=37)\end{array}$ & $\begin{array}{l}\text { PCR positive SARS-CoV-2 infection; no oxygen } \\
\text { supply due to COVID-19: WHO score } 1-3\end{array}$ \\
\hline $\begin{array}{l}\text { inflammatory control group (Ctrl-infl; } \\
n=14)\end{array}$ & $\begin{array}{l}\text { no SARS-CoV-2 infection (PCR); patient with } \\
\text { diagnosed infection/inflammation CRP }>0.5 \mathrm{mg} / \mathrm{dl} \text { or } \\
\text { IL-6 }>5.9 \mathrm{pg} / \mathrm{ml}\end{array}$ \\
\hline $\begin{array}{l}\text { healthy control group (Ctrl-noninfl; } \\
n=11)\end{array}$ & $\begin{array}{l}\text { no SARS-CoV-2 infection (PCR); CRP } \leq 0.5 \mathrm{mg} / \mathrm{dl} \\
\text { and IL-6 } \leq 5.9 \mathrm{pg} / \mathrm{ml}\end{array}$ \\
\hline Inflammation peak & $\begin{array}{l}\text { Time of the highest measured CRP or IL- } 6 \text { value } \\
\text { (whichever occurred later) broadened }+24 \mathrm{~h}\end{array}$ \\
\hline \multicolumn{2}{|l|}{ Disease phase } \\
\hline acute-early & $\begin{array}{l}\text { Interval between disease onset (symptoms and/or } \\
\text { positive PCR test) until 24h post inflammation peak }\end{array}$ \\
\hline acute-late & $\begin{array}{l}\text { Interval starting } 24 \mathrm{~h} \text { post inflammation peak until } \\
\text { hospital discharge }\end{array}$ \\
\hline recovery & Time after hospital discharge \\
\hline Biospecimen & Heparin plasma \\
\hline Sample analysis & Proteomics: Olink Explore 1536/384 \\
\hline Routine biochemical indices & 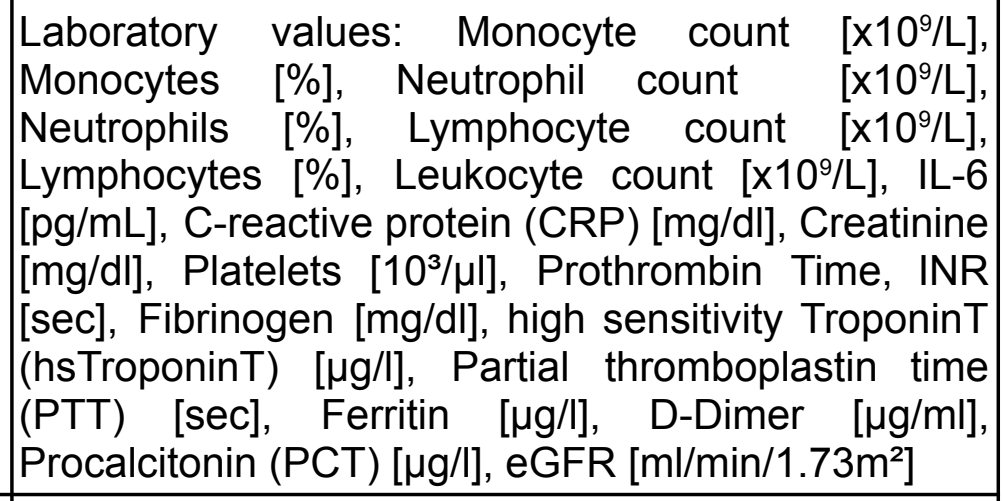 \\
\hline Comorbidity (groups) & $\begin{array}{l}\text { Diabetes, high cholesterol, cardiovascular disease, } \\
\text { lung disease, kidney disease, immuno-compromised } \\
\text { status, steroid intake during or before proteomics } \\
\text { sampling, superinfection during proteomics sampling }\end{array}$ \\
\hline
\end{tabular}


medRxiv preprint doi: https://doi.org/10.1101/2022.03.02.22271106; this version posted March 6, 2022. The copyright holder for this preprint (which was not certified by peer review) is the author/funder, who has granted medRxiv a license to display the preprint in perpetuity.

\section{Clinical Data Collection, patient grouping, and disease phase assignment}

The study prospectively enrolled 65 patients with PCR confirmed SARS-CoV-2 infection during the first phase of the COVID-19 pandemic in Germany (03/2020 to 08/2020), before steroid treatment for SARS-CoV-2 was routinely prescribed. Patients were enrolled shortly before or at the onset of the acute infection phase when laboratory signs of infection and disease-specific symptoms develop. Twenty-five patients with acute (inflammatory control group; Ctrl-infl) or no/low non-COVID-19 related inflammation (healthy control group; Ctrl-noninfl) were additionally included in the study as control groups. Patients and control subjects are part of the COVID-19 Registry of the LMU University Hospital Munich (CORKUM, WHO trial id DRKS00021225). Patient data were anonymized for analysis. The study was approved by the ethics committee of the Ludwig-Maximilians-Universität (LMU), Munich, Germany (Study title: "COVID-19 Register des LMU Klinikums (CORKUM)"; Project No: 20-245 (initial approval date: 03/2020; Amendment approval dates: 07/2020, 01/2021, 05/2021) as well as under the Project No: 20-259 (CPC-M bioArchive)).

Comprehensive electronic health records of all 90 patients were provided including baseline information like age, gender, medical background about comorbidities, and medication before hospital admission. Furthermore, information about the clinical course was provided including different routine biomedical indices (e.g., blood cell measurements), different inflammation markers like CRP, IL-6, or Ferritin, coagulation markers such as platelet count or PTT, and other body function values (e.g., creatinine or hsTroponinT, measured at admission as well as repeatedly over the hospital stay as needed), received treatments (e.g., ventilation or medication), and adverse events (e.g., acute kidney failure, thrombosis/embolism, or death).

COVID-19 patients were classified according to ordinal scale for clinical improvement of COVID-19 infection reported by the WHO (Blueprint, 2020) and grouped into two sub-cohorts based on the need for oxygen supply, i.e., disease severity (WHO $\geq 4$ - C19-ox; WHO $\leq 3$ - C19-nonox) (Figure 1A).

To specify the host immune response to COVID-19 infection while considering the underlying disease phase, we developed a novel approach for a high-risk, 
medRxiv preprint doi: https://doi.org/10.1101/2022.03.02.22271106; this version posted March 6, 2022. The copyright holder for this preprint (which was not certified by peer review) is the author/funder, who has granted medRxiv a license to display the preprint in perpetuity. It is made available under a CC-BY-NC-ND 4.0 International license .

multimorbid patient cohort to improve upon general time-of-infection based approaches (e.g., (Schulte-Schrepping et al, 2020)) or approaches using thresholds for levels of inflammation markers (e.g., (Herold et al, 2020; Chen et al, 2020a)). As IL-6 (> $80 \mathrm{pg} / \mathrm{mL}$ ) and CRP levels (> $97 \mathrm{mg} / \mathrm{L}$ ) correctly classified $80 \%$ of patients regarding their risk of respiratory failure (Herold et al, 2020), we used these markers and extended this approach by defining disease phases based on individual trajectories while considering important clinical hallmarks. Using inflammation markers, we individually identified an inflammation peak for each patient, defined as the time point of the highest measured CRP or IL-6 value (whichever occurred later) broadened by a window of $24 \mathrm{~h}$ after this peak to account for individual differences in inflammation marker decline. Accordingly, a total of three disease phases were distinguished: COVID-19-acute-early, COVID-19-acute-late, and COVID-19-recovery phase. The COVID-19-acute-early phase was defined as the time between disease onset, i.e., the onset of clinical symptoms and/or first positive PCR test and the end of the inflammation peak. The COVID-19-acute-late phase was defined as the time after the inflammation peak until hospital discharge. The COVID-19-recovery phase was defined as the time after hospital discharge.

In cases with significant discrepancy of disease severity, i.e., maximum WHO score at admission and the individual trajectory of IL-6 and CRP, the samples were assigned to the acute-late phase, assuming a surpassed inflammation peak at admission (Figure 1B, Figure S1). Three samples (Patient 12 and 18, Figure S1) without any IL-6 and CRP peaks were assigned based on the proteomic data, by applying a k-nearest neighbors clustering algorithm to assign the samples to their most likely disease phase while validating clinical symptoms for group assignment.

Non-C19 patients were assigned to two control groups based on the presence of inflammation: We included 14 patients with acute non-COVID related inflammation (Ctrl-infl) characterized by a maximum CRP $>0.5 \mathrm{mg} / \mathrm{dl}$ or IL-6 $>5.9 \mathrm{pg} / \mathrm{ml}$ and 11 subjects without elevated inflammation markers (Ctrl-noninfl), i.e., CRP $\leq 0.5 \mathrm{mg} / \mathrm{dl}$ and IL-6 $\leq 5.9 \mathrm{pg} / \mathrm{ml}$ (Figure 1A). Phase and group definitions can be found in Table 1. 
medRxiv preprint doi: https://doi.org/10.1101/2022.03.02.22271106; this version posted March 6, 2022. The copyright holder for this preprint (which was not certified by peer review) is the author/funder, who has granted medRxiv a license to display the preprint in perpetuity.

\section{Sample Collection and Processing}

A total of 129 samples were collected in all study subjects with one to five serial samples over the different phases and subjected to proteomic analysis. Plasma was separated from heparinized whole blood by centrifugation at 2,000 $\mathrm{g}$ for 15 minutes at room temperature and immediately stored at $-80^{\circ} \mathrm{C}$ until preparation for proteome analysis.

\section{Olink plasma proteomics}

The Olink® Explore 1536 platform was used to measure protein abundance in plasma samples. The full library consisting of four 384-plex panels (Inflammation, Oncology, Cardiometabolic, and Neurology) was used to screen 1,472 proteins. Relative protein abundance was calculated from the number of matched counts on the Illumina NovaSeq 6000 run using two $S 1$ flow cells with $2 \times 50$ base read lengths. The counts of protein specific-barcode sequences were transformed into Normalized Protein eXpression (NPX) units and an intensity normalization algorithm was applied to reduce the technical variation. The final data were provided in the arbitrary unit (NPX) on a log2 scale. Quality control (QC) was performed at both protein and sample levels. Three internal controls are spiked into each sample in order to monitor the quality of assay performance, as well as the quality of individual samples. Following criteria are applied to pass the sample QC: the average matched counts for each sample must exceed 500 counts; the deviation from the median value of the incubation- and amplification controls for each sample should not exceed +/-0.3 NPX for either of the internal controls. We, therefore, excluded 8 samples, whose mean of the failing proteins deviated more than 0.5 standard deviations from the overall mean of all samples which passed QC. As a further QC instance for comparability, the three proteins TNF, CXCL8, and IL-6 were measured in each of the four Olink® Explore panels. Since all four measurements were highly correlated for each of the three proteins (TNF: $r=0.952-0.965 ;$ CXCL8: $r=0.989-0.998$; IL-6: $r=0.979-0.997$ ), we kept only one representative for each protein based on the minimal number of QC warnings, conformity in scatter plots, and population variances. Furthermore, Olink ${ }^{\circledR}$ recommends that proteins with a large proportion of samples below the limit of detection (LOD) should be excluded from the 
medRxiv preprint doi: https://doi.org/10.1101/2022.03.02.22271106; this version posted March 6,2022 . The copyright holder for this preprint
(which was not certified by peer review) is the author/funder, who has granted medRxiv a license to display the preprint in perpetuity. It is made available under a CC-BY-NC-ND 4.0 International license .

analysis. We, therefore, excluded 77 proteins that were under the LOD in more than $25 \%$ of samples in all study groups.

\section{Data analysis}

We compared clinical covariates and routine biochemical indices within the first 24 hours after hospital admission separately for C19-ox and C19-nonox with both control groups (Ctrl-infl and Ctrl-noninfl). In addition, we analyzed routine biochemical indices and plasma proteomics by (1) comparing each phase (acute-early, acute-late, recovery) separately with both control groups (Ctrl-infl and Ctrl-noninfl) - overall (i.e., severity-independent), and within C19-ox and C19-nonox; (2) comparing the phases (acute-early, acute-late, recovery) with each other - overall (severity-independent) and within C19-ox and C19-nonox; and (3) comparing the two severity groups (C19-ox and C19-nonox) with each other in each phase (acute-early, acute-late, recovery).

Continuous and categorical variables were presented as median (interquartile range (IQR) with $25 \%$ and $75 \%$ percentiles) and $n(\%)$ respectively. We used the Mann-Whitney-Wilcoxon test, Welch test, Tukey's range test, $X^{2}$ test, and Dirichlet regression to compare differences between the $\mathrm{C} 19$ groups and the Ctrl-infl I Ctrl-noninfl control groups where appropriate. All tests were two-sided, and a P-value less than 0.05 was considered statistically significant. We used Python's SciPy package (Inglett et al, 2015) to perform the statistical analysis. The effect sizes are described as log2 fold change (FC).

For the proteomics analysis, we used the $\mathrm{R}$ package limma ("Linear models for microarray data") (Ritchie et al, 2015) adjusted for the following confounders: age, gender, cardiovascular diseases, diabetes, high cholesterol, lung disease, kidney disease, immuno-compromised status, superinfection during proteomics sampling, steroid treatment during hospital stay during or before proteomics sampling (Table S11). Volcano Plots were created using the R package EnhancedVolcano (Blighe et al, 2019). We conducted overrepresentation tests (based on hypergeometric models with a minimum count of three proteins) for biological processes and pathways using ClusterProfiler ( $\mathrm{Yu}$ et al, 2012) and ReactomePA (Yu \& He, 2016), while the Enrichplot (Yu, 2018) package was used for visualization of the overrepresentation results. All tests for the proteomics analysis were corrected for multiple testing using 
medRxiv preprint doi: https://doi.org/10.1101/2022.03.02.22271106; this version posted March 6, 2022. The copyright holder for this preprint (which was not certified by peer review) is the author/funder, who has granted medRxiv a license to display the preprint in perpetuity. It is made available under a CC-BY-NC-ND 4.0 International license .

Benjamini-Hochberg correction, where a P-value less than 0.05 was considered statistically significant.

For the significance tests, one sample per person was used in order to avoid autocorrelation. For the acute-early and acute-late phases, we used the proteomics sample, which was collected closest in time to the median difference to the inflammation peak in that phase. For comparisons with the recovery phase, we always used the very last sample, no matter which group it was compared to, in order to keep the sample size as large as possible. In the non-C19 group, only one person had serial samples. We used the sample which was closest to the median CRP value of the non-C19 group.

We chose the clinical sampling closest to the proteomics sampling and accepted a range of four days (Figure S6). Not all biochemical indices were available at any given time point (Figure S7). Furthermore, no D-Dimer and IL-6 values were available in the Ctrl-noninfl group.

\section{Acknowledgments}

We would like to thank all CORKUM investigators and staff. The authors thank the patients and their families for their participation in the CORKUM registry.

\section{Funding}

This study was supported by COMBAT C19IR (01KI20249), funded by the Federal Ministry of Education and Research (BMBF) and the Free State of Bavaria under the Excellence Strategy of the Federal and State Government (LMUexcellent), as well as partially funded by the Bavarian Ministry for Economic Affairs, Regional Development and Energy as part of a project to support the thematic development of the Institute for Cognitive Systems (IKS). The present study was supported by the German Center for Lung Research (DZL, German Ministry of Education and Health (BMBF)) as well as the Research Training Group Targets in Toxicology (GRK2338) of the German Science and Research Organization (DFG). Additional financial support was provided by the Stiftung AtemWeg (LSS AIRR) and by the Helmholtz Association's Initiative and Networking Fund through Helmholtz Al. 
medRxiv preprint doi: https://doi.org/10.1101/2022.03.02.22271106; this version posted March 6, 2022. The copyright holder for this preprint

\section{Author contribution}

Data Curation: Johannes C. Helmuth, Clemens Scherer, Maximilian Muenchhoff, Project administration: Benjamin Schubert and Anne Hilgendorff; Funding acquisition: Stefanie M. Hauck, Jürgen Behr, Li Deng, Narges Ahmidi, Benjamin Schubert, Anne Hilgendorff; Investigation: Johannes C. Helmuth, Clemens Scherer, Maximilian Muenchhoff, Rainer Kaiser; Methodology: Alina Bauer, Elisabeth Pachl, Benjamin Schubert.; Resources: Johannes C. Hellmuth, Clemens Scherer, Maximilian Muenchhoff, Marion Frankenberger, Stefanie M. Hauck, Daniel Teupser, Nikolaus Kneidinger, Hans Stubbe, Agnese Petrera; Software: Alina Bauer and Elisabeth Pachl; Supervision: Narges Ahmidi, Benjamin Schubert, Anne Hilgendorff; Validation: Benjamin Schubert, Anne Higendorff, Jürgen Behr, Rainer Kaiser, Daniel Teupser; Bernhard Ryffe; Visualization: Alina Bauer and Elisabeth Pachl; Writing original draft: Alina Bauer and Elisabeth Pachl; Writing - review and editing: Benjamin Schubert and Anne Hilgendorff; All authors commented on previous versions of the manuscript. All authors read and approved the final manuscript.

\section{Disclosure and competing interests statement}

The authors declare no conflict of interest apart from Clemens Scherer, who received speaker honoraria from AstraZeneca, outside the submitted work. All authors were involved in the decision to publish and reviewed the article before submission.

\section{Data Availability Section}

The data that support the findings of this study are available from the corresponding authors upon request. Access to data for research purposes is possible for eligible institutes according to GDPR rules. 
medRxiv preprint doi: https://doi.org/10.1101/2022.03.02.22271106; this version posted March 6, 2022. The copyright holder for this preprint (which was not certified by peer review) is the author/funder, who has granted medRxiv a license to display the preprint in perpetuity.

\section{References}

Abrahim SA, Tessema M, Defar A, Hussen A, Ejeta E, Demoz G, Tereda AB, Dillnessa E, Feleke A, Amare M, et al (2020) Time to recovery and its predictors among adults hospitalized with COVID-19: A prospective cohort study in Ethiopia. PLoS One 15: e0244269

Al-Ani F, Chehade S \& Lazo-Langner A (2020) Thrombosis risk associated with COVID-19 infection. A scoping review. Thromb Res 192: 152-160

Arango Duque G \& Descoteaux A (2014) Macrophage cytokines: involvement in immunity and infectious diseases. Front Immunol 5: 491

Bai M, Grieshaber-Bouyer R, Wang J, Schmider AB, Wilson ZS, Zeng L, Halyabar O, Godin MD, Nguyen HN, Levescot A, et al (2017) CD177 modulates human neutrophil migration through activation-mediated integrin and chemoreceptor regulation. Blood 130: 2092-2100

Bardoel BW, Kenny EF, Sollberger G \& Zychlinsky A (2014) The Balancing Act of Neutrophils. Cell Host Microbe 15: 526-536

Bastard P, Rosen LB, Zhang Q, Michailidis E, Hoffmann H-H, Zhang Y, Dorgham K, Philippot Q, Rosain J, Béziat V, et al (2020) Autoantibodies against type I IFNs in patients with life-threatening COVID-19. Science 370

Bernardes JP, Mishra N, Tran F, Bahmer T, Best L, Blase JI, Bordoni D, Franzenburg J, Geisen U, Josephs-Spaulding J, et al (2020) Longitudinal Multi-omics Analyses Identify Responses of Megakaryocytes, Erythroid Cells, and Plasmablasts as Hallmarks of Severe COVID-19. Immunity 53: 1296-1314.e9

Bhapkar HR, Mahalle PN, Dey N \& Santosh KC (2020) Revisited COVID-19 Mortality and Recovery Rates: Are we Missing Recovery Time Period? J Med Syst 44: 202

Blighe K, Rana S \& EnhancedVolcano LM (2019) Publication-ready volcano plots with enhanced colouring and labeling. R-Package version 1.2. 0. [PREPRINT]

Blueprint W (2020) novel Coronavirus. COVID-19 Therapeutic Trial Synopsis Available online: https://www who int/blueprint/priority-diseases/key-action/COVID-19_Treatment_Trial_Design_Ma ster_Protocol_synopsis_Final_18022020 pdf (accessed on 5 February 2021)

Booth A, Reed AB, Ponzo S, Yassaee A, Aral M, Plans D, Labrique A \& Mohan D (2021) Population risk factors for severe disease and mortality in COVID-19: A global systematic review and meta-analysis. PLoS One 16: e0247461

Boyarsky BJ, Werbel WA, Avery RK, Tobian AAR, Massie AB, Segev DL \& Garonzik-Wang JM (2021) Antibody Response to 2-Dose SARS-CoV-2 mRNA Vaccine Series in Solid Organ Transplant Recipients. JAMA 325: 2204-2206

Brinkmann V, Reichard U, Goosmann C, Fauler B, Uhlemann Y, Weiss DS, 
medRxiv preprint doi: https://doi.org/10.1101/2022.03.02.22271106; this version posted March 6, 2022. The copyright holder for this preprint (which was not certified by peer review) is the author/funder, who has granted medRxiv a license to display the preprint in perpetuity. It is made available under a CC-BY-NC-ND 4.0 International license .

Weinrauch Y \& Zychlinsky A (2004) Neutrophil extracellular traps kill bacteria. Science 303: 1532-1535

Bussani R, Schneider E, Zentilin L, Collesi C, Ali H, Braga L, Volpe MC, Colliva A, Zanconati F, Berlot G, et al (2020) Persistence of viral RNA, pneumocyte syncytia and thrombosis are hallmarks of advanced COVID-19 pathology. EBioMedicine 61: 103104

Buszko M, Nita-Lazar A, Park J-H, Schwartzberg PL, Verthelyi D, Young HA \& Rosenberg AS (2021) Lessons learned: new insights on the role of cytokines in COVID-19. Nat Immunol 22: 404-411

Castro F, Cardoso AP, Gonçalves RM, Serre K \& Oliveira MJ (2018)

Interferon-Gamma at the Crossroads of Tumor Immune Surveillance or Evasion. Front Immunol 9: 847

Chen B, Jiang C, Han B, Guan C, Fang G, Yan S, Wang K, Liu L, Conlon CP, Xie R, et al (2021) High prevalence of occult thrombosis in cases of mild/moderate COVID-19. Int J Infect Dis 104: 77-82

Chen LYC, Hoiland RL, Stukas S, Wellington CL \& Sekhon MS (2020a) Confronting the controversy: interleukin- 6 and the COVID-19 cytokine storm syndrome. Eur Respir J 56

Chen N, Zhou M, Dong X, Qu J, Gong F, Han Y, Qiu Y, Wang J, Liu Y, Wei Y, et al (2020b) Epidemiological and clinical characteristics of 99 cases of 2019 novel coronavirus pneumonia in Wuhan, China: a descriptive study. Lancet 395: $507-513$

Chen R, Zhu S, Zeng L, Wang Q, Sheng Y, Zhou B, Tang D \& Kang R (2019a) AGER-Mediated Lipid Peroxidation Drives Caspase-11 Inflammasome Activation in Sepsis. Front Immunol 10: 1904

Chen Y-C, Gonzalez ME, Burman B, Zhao X, Anwar T, Tran M, Medhora N, Hiziroglu AB, Lee W, Cheng Y-H, et al (2019b) Mesenchymal Stem/Stromal Cell Engulfment Reveals Metastatic Advantage in Breast Cancer. Cell Rep 27: 3916-3926.e5

Clavijo MM, Vicente Reparaz M de LA, Ruiz JI, Acuña MA, Casali CE, Aizpurua MF, Mahuad CV, Eciolaza S, Ventura A \& Garate GM (2021) Mild COVID-19 IIIness as a Risk Factor for Venous Thromboembolism. Cureus 13: e18236

Daigo K, Takamatsu Y \& Hamakubo T (2016) The Protective Effect against Extracellular Histones Afforded by Long-Pentraxin PTX3 as a Regulator of NETs. Front Immunol 7: 344

Demichev V, Tober-Lau P, Lemke O, Nazarenko T, Thibeault C, Whitwell H, Röhl A, Freiwald A, Szyrwiel L, Ludwig D, et al (2021) A time-resolved proteomic and prognostic map of COVID-19. Cell Syst 12: 780-794.e7

Devreese KMJ (2021) COVID-19-related laboratory coagulation findings. Int J Lab 
medRxiv preprint doi: https://doi.org/10.1101/2022.03.02.22271106; this version posted March 6, 2022. The copyright holder for this preprint (which was not certified by peer review) is the author/funder, who has granted medRxiv a license to display the preprint in perpetuity.

Hematol 43 Suppl 1: 36-42

Faust JS, Lin Z \& Del Rio C (2020) Comparison of Estimated Excess Deaths in New York City During the COVID-19 and 1918 Influenza Pandemics. JAMA Netw Open 3: e2017527

Filbin MR, Mehta A, Schneider AM, Kays KR, Guess JR, Gentili M, Fenyves BG, Charland NC, Gonye ALK, Gushterova I, et al (2021) Longitudinal proteomic analysis of severe COVID-19 reveals survival-associated signatures, tissue-specific cell death, and cell-cell interactions. Cell Rep Med 2: 100287

Geyer PE, Arend FM, Doll S, Louiset M-L, Virreira Winter S, Müller-Reif JB, Torun FM, Weigand M, Eichhorn P, Bruegel M, et al (2021) High-resolution serum proteome trajectories in COVID-19 reveal patient-specific seroconversion. EMBO Mol Med 13: e14167

Grasselli G, Greco M, Zanella A, Albano G, Antonelli M, Bellani G, Bonanomi E, Cabrini L, Carlesso E, Castelli G, et al (2020) Risk Factors Associated With Mortality Among Patients With COVID-19 in Intensive Care Units in Lombardy, Italy. JAMA Intern Med 180: 1345-1355

Guan W-J, Ni Z-Y, Hu Y, Liang W-H, Ou C-Q, He J-X, Liu L, Shan H, Lei C-L, Hui DSC, et al (2020) Clinical Characteristics of Coronavirus Disease 2019 in China. N Engl J Med 382: 1708-1720

Haljasmägi L, Salumets A, Rumm AP, Jürgenson M, Krassohhina E, Remm A, Sein $\mathrm{H}$, Kareinen L, Vapalahti O, Sironen T, et al (2020) Longitudinal proteomic profiling reveals increased early inflammation and sustained apoptosis proteins in severe COVID-19. Sci Rep 10: 20533

Herold T, Jurinovic V, Arnreich C, Lipworth BJ, Hellmuth JC, von Bergwelt-Baildon M, Klein M \& Weinberger T (2020) Elevated levels of IL-6 and CRP predict the need for mechanical ventilation in COVID-19. J Allergy Clin Immunol 146: 128-136.e4

Hodges G, Pallisgaard J, Schjerning Olsen A-M, McGettigan P, Andersen M, Krogager M, Kragholm K, Køber L, Gislason GH, Torp-Pedersen C, et al (2020) Association between biomarkers and COVID-19 severity and mortality: a nationwide Danish cohort study. BMJ Open 10: e041295

Hsu F-C, Sides EG, Mychaleckyj JC, Worrall BB, Elias GA, Liu Y, Chen W-M, Coull BM, Toole JF, Rich SS, et al (2011) Transcobalamin 2 variant associated with poststroke homocysteine modifies recurrent stroke risk. Neurology 77: 1543-1550

Hsu Y-A, Chang C-Y, Lan J-L, Li J-P, Lin H-J, Chen C-S, Wan L \& Liu F-T (2020) Amelioration of bleomycin-induced pulmonary fibrosis via TGF- $\beta$-induced Smad and non-Smad signaling pathways in galectin-9-deficient mice and fibroblast cells. J Biomed Sci 27: 24

Huang C, Wang Y, Li X, Ren L, Zhao J, Hu Y, Zhang L, Fan G, Xu J, Gu X, et al 
medRxiv preprint doi: https://doi.org/10.1101/2022.03.02.22271106; this version posted March 6, 2022. The copyright holder for this preprint (which was not certified by peer review) is the author/funder, who has granted medRxiv a license to display the preprint in perpetuity. It is made available under a CC-BY-NC-ND 4.0 International license .

(2020) Clinical features of patients infected with 2019 novel coronavirus in Wuhan, China. Lancet 395: 497-506

Inglett GE, Chen D \& Liu SX (2015) Pasting and rheological properties of quinoa-oat composites. Int J Food Sci Technol 50: 878-884

Jin Y-H, Cai L, Cheng Z-S, Cheng H, Deng T, Fan Y-P, Fang C, Huang D, Huang L-Q, Huang Q, et al (2020) A rapid advice guideline for the diagnosis and treatment of 2019 novel coronavirus (2019-nCoV) infected pneumonia (standard version). Mil Med Res 7: 4

Jin Y, Li J, Chen J, Shao M, Zhang R, Liang Y, Zhang X, Zhang X, Zhang Q, Li F, et al (2019) Tissue-Specific Autoantibodies Improve Diagnosis of Primary Sjögren's Syndrome in the Early Stage and Indicate Localized Salivary Injury. Journal of Immunology Research 2019

Juthani PV, Gupta A, Borges KA, Price CC, Lee AI, Won CH \& Chun HJ (2021) Hospitalisation among vaccine breakthrough COVID-19 infections. Lancet Infect Dis

Kaiser R, Leunig A, Pekayvaz K, Popp O, Joppich M, Polewka V, Escaig R, Anjum A, Hoffknecht M-L, Gold C, et al (2021) Self-sustaining IL-8 loops drive a prothrombotic neutrophil phenotype in severe COVID-19. JCI Insight 6

Karki R, Sharma BR, Tuladhar S, Williams EP, Zalduondo L, Samir P, Zheng M, Sundaram B, Banoth B, Malireddi RKS, et al (2021) Synergism of TNF- $\alpha$ and IFN-y Triggers Inflammatory Cell Death, Tissue Damage, and Mortality in SARS-CoV-2 Infection and Cytokine Shock Syndromes. Cell 184: 149-168.e17

Lam SM, Zhang C, Wang Z, Ni Z, Zhang S, Yang S, Huang X, Mo L, Li J, Lee B, et al (2021) A multi-omics investigation of the composition and function of extracellular vesicles along the temporal trajectory of COVID-19. Nat Metab 3: 909-922

Liu F, Li L, Xu M, Wu J, Luo D, Zhu Y, Li B, Song X \& Zhou X (2020a) Prognostic value of interleukin-6, C-reactive protein, and procalcitonin in patients with COVID-19. J Clin Virol 127: 104370

Liu J, Zhang S, Wu Z, Shang Y, Dong X, Li G, Zhang L, Chen Y, Ye X, Du H, et al (2020b) Clinical outcomes of COVID-19 in Wuhan, China: a large cohort study. Ann Intensive Care 10: 99

Liu X, Arfman T, Wichapong K, Reutelingsperger CPM, Voorberg J \& Nicolaes GAF (2021) PAD4 takes charge during neutrophil activation: Impact of PAD4 mediated NET formation on immune-mediated disease. J Thromb Haemost 19: 1607-1617

Lombardi A, Trombetta E, Cattaneo A, Castelli V, Palomba E, Tirone M, Mangioni D, Lamorte G, Manunta M, Prati D, et al (2020) Early Phases of COVID-19 Are Characterized by a Reduction in Lymphocyte Populations and the Presence of Atypical Monocytes. Front Immunol 11: 560330 
medRxiv preprint doi: https://doi.org/10.1101/2022.03.02.22271106; this version posted March 6, 2022. The copyright holder for this preprint (which was not certified by peer review) is the author/funder, who has granted medRxiv a license to display the preprint in perpetuity. It is made available under a CC-BY-NC-ND 4.0 International license .

Malinis M, Cohen E \& Azar MM (2021) Effectiveness of SARS-CoV-2 vaccination in fully vaccinated solid organ transplant recipients. Am J Transplant 21:

2916-2918

Messner CB, Demichev V, Wendisch D, Michalick L, White M, Freiwald A, Textoris-Taube K, Vernardis SI, Egger A-S, Kreidl M, et al (2020)

Ultra-High-Throughput Clinical Proteomics Reveals Classifiers of COVID-19 Infection. Cell Syst 11: 11-24.e4

Middleton EA, He X-Y, Denorme F, Campbell RA, Ng D, Salvatore SP, Mostyka M, Baxter-Stoltzfus A, Borczuk AC, Loda M, et al (2020) Neutrophil extracellular traps contribute to immunothrombosis in COVID-19 acute respiratory distress syndrome. Blood 136: 1169-1179

Misharin AV, Morales-Nebreda L, Reyfman PA, Cuda CM, Walter JM, McQuattie-Pimentel AC, Chen C-I, Anekalla KR, Joshi N, Williams KJN, et al (2017) Monocyte-derived alveolar macrophages drive lung fibrosis and persist in the lung over the life span. J Exp Med 214: 2387-2404

Münzer P, Negro R, Fukui S, di Meglio L, Aymonnier K, Chu L, Cherpokova D, Gutch S, Sorvillo N, Shi L, et al (2021) NLRP3 Inflammasome Assembly in Neutrophils Is Supported by PAD4 and Promotes NETosis Under Sterile Conditions. Front Immunol 12: 683803

Münzer P, Negro R, Magupalli V, Kittisopikul M, Vahabikashi A, Wong SL, Goldman R, Wu H, Ridge K \& Wagner D (2019) Assembly of the NIrp3 Inflammasome Regulates NET Formation and is Promoted by the Vimentin Intermediate Filament Cytoskeletal System. Arterioscler Thromb Vasc Biol 39: A118-A118

Nachtigall I, Lenga P, Jóźwiak K, Thürmann P, Meier-Hellmann A, Kuhlen R, Brederlau J, Bauer T, Tebbenjohanns J, Schwegmann K, et al (2020) Clinical course and factors associated with outcomes among 1904 patients hospitalized with COVID-19 in Germany: an observational study. Clin Microbiol Infect 26: 1663-1669

Nicolai L, Leunig A, Brambs S, Kaiser R, Weinberger T, Weigand M, Muenchhoff M, Hellmuth JC, Ledderose S, Schulz H, et al (2020) Immunothrombotic Dysregulation in COVID-19 Pneumonia Is Associated With Respiratory Failure and Coagulopathy. Circulation 142: 1176-1189

Ovies C, Semmes EC \& Coyne CB (2021) Pregnancy influences immune responses to SARS-CoV-2. Sci Transl Med 13: eabm2070

Oxford KL, Wendler JP, McDermott JE, White RA lii, Powell JD, Jacobs JM, Adkins JN \& Waters KM (2016) The landscape of viral proteomics and its potential to impact human health. Expert Rev Proteomics 13: 579-591

Park J, Kim H, Kim SY, Kim Y, Lee J-S, Dan K, Seong M-W \& Han D (2020) In-depth blood proteome profiling analysis revealed distinct functional characteristics of plasma proteins between severe and non-severe COVID-19 patients. Sci Rep 10: 22418 
medRxiv preprint doi: https://doi.org/10.1101/2022.03.02.22271106; this version posted March 6, 2022. The copyright holder for this preprint (which was not certified by peer review) is the author/funder, who has granted medRxiv a license to display the preprint in perpetuity.

Pekayvaz K, Leunig A, Kaiser R, Brambs S, Joppich M, Janjic A, Popp O, Polewka V, Wange LE, Gold C, et al (2021) Protective immune trajectories in early viral containment of non-pneumonic SARS-CoV-2 infection. bioRxiv: 2021.02.03.429351

Piroth L, Cottenet J, Mariet A-S, Bonniaud P, Blot M, Tubert-Bitter P \& Quantin C (2021) Comparison of the characteristics, morbidity, and mortality of COVID-19 and seasonal influenza: a nationwide, population-based retrospective cohort study. Lancet Respir Med 9: 251-259

Pišlar A, Mitrović A, Sabotič J, Fonović UP, Nanut MP, Jakoš T, Senjor E \& Kos J (2020) The role of cysteine peptidases in coronavirus cell entry and replication: The therapeutic potential of cathepsin inhibitors. PLoS Pathog 16: e1009013

Reddy NM, Hall SW \& MacKintosh FR (1999) Partial thromboplastin time: prediction of adverse events and poor prognosis by low abnormal values. Arch Intern Med 159: $2706-2710$

Ritchie ME, Phipson B, Wu D, Hu Y, Law CW, Shi W \& Smyth GK (2015) limma powers differential expression analyses for RNA-sequencing and microarray studies. Nucleic Acids Res 43: e47

Rubner Y, Tomasi C \& Guibas LJ (2000) The Earth Mover's Distance as a Metric for Image Retrieval. Int J Comput Vis 40: 99-121

Saadi H, Shan Y, Marazziti D \& Wray S (2019) GPR37 Signaling Modulates Migration of Olfactory Ensheathing Cells and Gonadotropin Releasing Hormone Cells in Mice. Front Cell Neurosci 13: 200

Schulte-Schrepping J, Reusch N, Paclik D, Baßler K, Schlickeiser S, Zhang B, Krämer B, Krammer T, Brumhard S, Bonaguro L, et al (2020) Severe COVID-19 Is Marked by a Dysregulated Myeloid Cell Compartment. Cell 182: 1419-1440.e23

Shatzman AR \& Henkin RI (1981) Gustin concentration changes relative to salivary zinc and taste in humans. Proc Natl Acad Sci U S A 78: 3867-3871

Shen B, Yi X, Sun Y, Bi X, Du J, Zhang C, Quan S, Zhang F, Sun R, Qian L, et al (2020) Proteomic and Metabolomic Characterization of COVID-19 Patient Sera. Cell 182: 59-72.e15

Shu T, Ning W, Wu D, Xu J, Han Q, Huang M, Zou X, Yang Q, Yuan Y, Bie Y, et al (2020) Plasma Proteomics Identify Biomarkers and Pathogenesis of COVID-19. Immunity 53: 1108-1122.e5

Smet A, Breugelmans T, Michiels J, Lamote K, Arras W, De Man JG, Heyndrickx L, Hauner A, Huizing M, Malhotra-Kumar S, et al (2021) A dynamic mucin mRNA signature associates with COVID-19 disease presentation and severity. $\mathrm{JCI}$ Insight 6

Spolski R, Li P \& Leonard WJ (2018) Biology and regulation of IL-2: from molecular 
medRxiv preprint doi: https://doi.org/10.1101/2022.03.02.22271106; this version posted March 6, 2022. The copyright holder for this preprint (which was not certified by peer review) is the author/funder, who has granted medRxiv a license to display the preprint in perpetuity. It is made available under a CC-BY-NC-ND 4.0 International license.

mechanisms to human therapy. Nat Rev Immunol 18: 648-659

Stavrou EX, Fang C, Bane KL, Long AT, Naudin C, Kucukal E, Gandhi A, Brett-Morris A, Mumaw MM, Izadmehr S, et al (2018) Factor XII and uPAR upregulate neutrophil functions to influence wound healing. $J$ Clin Invest 128 : 944-959

Tang L, Yin Z, Hu Y \& Mei H (2020) Controlling Cytokine Storm Is Vital in COVID-19. Front Immunol 0

Tolossa T, Wakuma B, Seyoum Gebre D, Merdassa Atomssa E, Getachew M, Fetensa G, Ayala D \& Turi E (2021) Time to recovery from COVID-19 and its predictors among patients admitted to treatment center of Wollega University Referral Hospital (WURH), Western Ethiopia: Survival analysis of retrospective cohort study. PLoS One 16: e0252389

Wang J, Li Q, Yin Y, Zhang Y, Cao Y, Lin X, Huang L, Hoffmann D, Lu M \& Qiu Y (2020) Excessive Neutrophils and Neutrophil Extracellular Traps in COVID-19. Front Immunol 0

WHO Coronavirus (COVID-19) Dashboard

Wiersinga WJ, Rhodes A, Cheng AC, Peacock SJ \& Prescott HC (2020) Pathophysiology, Transmission, Diagnosis, and Treatment of Coronavirus Disease 2019 (COVID-19): A Review. JAMA 324: 782-793

Wilk AJ, Rustagi A, Zhao NQ, Roque J, Martínez-Colón GJ, McKechnie JL, Ivison GT, Ranganath T, Vergara R, Hollis T, et al (2020) A single-cell atlas of the peripheral immune response in patients with severe COVID-19. Nat Med 26: 1070-1076

Williamson EJ, Walker AJ, Bhaskaran K, Bacon S, Bates C, Morton CE, Curtis HJ, Mehrkar A, Evans D, Inglesby P, et al (2020) Factors associated with COVID-19-related death using OpenSAFELY. Nature 584: 430-436

Winheim E, Rinke L, Lutz K, Reischer A, Leutbecher A, Wolfram L, Rausch L, Kranich J, Wratil PR, Huber JE, et al (2021) Impaired function and delayed regeneration of dendritic cells in COVID-19. PLoS Pathog 17: e1009742

Woodruff MC, Ramonell RP, Nguyen DC, Cashman KS, Saini AS, Haddad NS, Ley AM, Kyu S, Howell JC, Ozturk T, et al (2020) Extrafollicular B cell responses correlate with neutralizing antibodies and morbidity in COVID-19. Nat Immunol 21: 1506-1516

Yang L, Xie X, Tu Z, Fu J, Xu D \& Zhou Y (2021) The signal pathways and treatment of cytokine storm in COVID-19. Signal Transduct Target Ther 6: 255

Yu G (2018) Enrichplot: visualization of functional enrichment result. $R$ package version 1

Yu G \& He Q-Y (2016) ReactomePA: an R/Bioconductor package for reactome 
medRxiv preprint doi: https://doi.org/10.1101/2022.03.02.22271106; this version posted March 6, 2022. The copyright holder for this preprint

(which was not certified by peer review) is the author/funder, who has granted medRxiv a license to display the preprint in perpetuity. It is made available under a CC-BY-NC-ND 4.0 International license.

pathway analysis and visualization. Mol Biosyst 12: 477-479

Yu G, Wang L-G, Han Y \& He Q-Y (2012) clusterProfiler: an R package for comparing biological themes among gene clusters. OMICS 16: 284-287

Zhang J-J, Dong X, Cao Y-Y, Yuan Y-D, Yang Y-B, Yan Y-Q, Akdis CA \& Gao Y-D (2020a) Clinical characteristics of 140 patients infected with SARS-CoV-2 in Wuhan, China. Allergy 75: 1730-1741

Zhang Q, Bastard P, Liu Z, Le Pen J, Moncada-Velez M, Chen J, Ogishi M, Sabli IKD, Hodeib S, Korol C, et al (2020b) Inborn errors of type I IFN immunity in patients with life-threatening COVID-19. Science 370: eabd4570

Zheng D, Liwinski T \& Elinav E (2020) Inflammasome activation and regulation: toward a better understanding of complex mechanisms. Cell Discov 6: 36

Zhou F, Yu T, Du R, Fan G, Liu Y, Liu Z, Xiang J, Wang Y, Song B, Gu X, et al (2020) Clinical course and risk factors for mortality of adult inpatients with COVID-19 in Wuhan, China: a retrospective cohort study. Lancet 395: 1054-1062

Zhou Y, Tao W, Shen F, Du W, Xu Z \& Liu Z (2021) The Emerging Role of Neutrophil Extracellular Traps in Arterial, Venous and Cancer-Associated Thrombosis. Front Cardiovasc Med 8: 786387 